\title{
ABSURDITY IN DISGUISE: How COURTS CREATE StATUTORY AMBiguity TO CONCEAL THEIR APPLICATION OF THE ABSURDITY DOCTRINE
}

\author{
Laura R. Dove*
}

Although explicitly invoked only in rare cases, the absurdity doctrine is far more robust in practice than commonly assumed. This is because of a phenomenon I call "absurdity in disguise," wherein judges use the anomalous or undesirable results of applying a statute's ordinary meaning to "create" statutory ambiguity, opening the door to a variety of interpretive tools that would otherwise be unavailable. Ironically, the use of ambiguity to conceal the use of the absurdity doctrine is a direct result of judges' increasing acceptance of textualist methods of statutory interpretation. Because textualism eschews results-oriented interpretive approaches, judges who wish to avoid a result of applying statutory text as written must employ text-centric arguments to do so. This article identifies the concept of absurdity in disguise and reveals its use in a variety of decisions at all levels of the federal courts.

\section{TABLE OF CONTENTS}

INTRODUCTION

I. The TENSION Between TeXtualism AND THE ABSURDity

DOCTRINE

A. Textualist Interpretation and Textualism's Rise

B. The Absurdity Doctrine

C. Textualism and the Absurdity Doctrine: In Tension at Best, Irreconcilable at Worst....

II. ABSURDITY IN DisGUISE: THE Role OF AMBIGUITY .......................... 758

III. ABSURDITY IN DISGUISE IN PRACTICE: EXAMPLES FROM RECENT

CASES

A. Bond v. United States............................................................. 767

B. Asadi v. G.E. Energy (USA), LLC ........................................ 772

C. National Federation of Independent Business v. Sebelius .......... 777

* Associate Professor of Law, Department of Management, Human Resources \& Law Troy University 137P Bibb Graves Hall Troy, AL 36082 dovel@troy.edu. The author wishes to thank the editors of the Nevada Law Journal for their work in preparing this manuscript for publication. 
D. King v. Burwell and Halbig v. Burwell 779

1. King v. Burwell in the Fourth Circuit .................................. 780

2. Halbig v. Burwell in the D.C. Circuit .................................... 783

3. The Supreme Court's Decision in King v. Burwell ............... 784

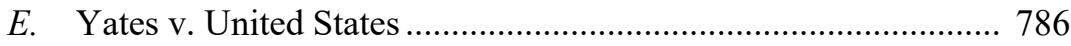

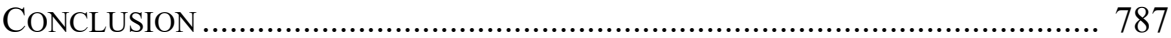

The process of judicial reform requires three steps. The first of these is to divine some single "purpose" which the statute serves. This is done although not one statute in a hundred has any such single purpose, and although the objectives of nearly every statute are differently interpreted by the different classes of its sponsors. The second step is to discover that a mythical being called "the legislator," in the pursuit of this imagined "purpose," overlooked something or left some gap or imperfection in his work. Then comes the final and most refreshing part of the task, which is, of course, to fill in the blank thus created. Quod erat faciendum. ${ }^{1}$

\section{INTRODUCTION}

That judges make law, rather than merely discover it, has been broadly (if grudgingly) acknowledged at least since the advent of legal realism. ${ }^{2}$ Yet judges' discomfort in acknowledging this fact-and attempts to obscure their lawmaking - have also been well documented. ${ }^{3}$ Judicial and scholarly proponents of textualism, a method of statutory interpretation, are some of the most vocal

1 Lon L. Fuller, The Case of the Speluncean Explorers, 62 HARV. L. REV. 616, 634 (1949).

2 See Antonin Scalia \& Bryan A. Garner, Reading Law: The InTERPREtation of Legal TEXTs 5 (2012) ("It used to be said that judges do not 'make' law-they simply apply it. In the 20th century, the legal realists convinced everyone that judges do indeed make law. To the extent that this was true, it was knowledge that the wise already possessed and the foolish could not be trusted with.").

${ }^{3}$ Cf. Nicholas S. Zeppos, The Use of Authority in Statutory Interpretation: An Empirical Analysis, 70 TEX. L. REV. 1073, 1108 (1992) ("Although the data reveal a role for practical considerations, it is quite likely that these figures undercount the role such consequentialist concerns play in the Court's decisionmaking [sic] process. As commentators have repeatedly suggested, practical considerations are masked by the invocation of more formal sources of authority."). In the same article, Professor Zeppos noted that originalist interpretive theories were based on "claims that fidelity to the enacting legislature is needed to counter anxiety over judicial lawmaking" and that "[t]he new textualism seeks to eliminate nontextual sources of authority from judicial consideration, also with the goal of constraining the judge." Id. at 1074. However, Professor Zeppos contrasted these views with those of scholars and judges advocating for "dynamic" interpretation methods do not necessarily see judicial lawmaking as an improper end of interpretation. Id. at 1088. But see SCALIA \& GARNER, supra note 2 , at 5 , for the contention that, in contrast to the decision-making process in common law cases, "good judges dealing with statutes do not make law. They do not 'give new content' to the statute, but merely apply the content that has been there all along, awaiting application to myriad factual scenarios." Scalia and Garner lament that some judges have accepted the invitation to make law improperly under the guise of statutory interpretation. SCALIA \& GARNER, supra note 2, at 7. 
in denouncing judicial intrusion into the policy and lawmaking realm of legislatures. Textualism emphasizes the determination of statutory meaning based on the ordinary meaning of a statute's text; it rejects attempts to circumvent or even supplement the apparent meaning of statutory text through inquiries into the enacting legislature's intention or purpose. ${ }^{4}$ For textualists, statutes simply mean what they say.

Scholars have thoroughly documented a strong textualist shift within the Supreme Court over the last few decades..$^{5}$ In light of textualism's profound influence, judges are highly attuned to the separation of powers concerns underlying the doctrine's efforts to restrict judicial interference with the legislative role. Yet, the gap between what judges do and what they say they do has, perhaps ironically, only grown with the popularity of textualism as a statutory interpretation method. At first blush, the contention that textualism has widened the gap between what judges do and what they purport to do seems counterintuitive. One of textualism's explicit goals is to restrict improper judicial lawmaking. ${ }^{6}$ If textualism has been so successful, there should be less (improper) lawmaking in the first place; therefore, any need to conceal it should likewise have diminished.

To shed light on this paradox, another phenomenon must be examined in tandem with the rise of textualism: the declining acceptance of the absurdity doctrine. ${ }^{7}$ The absurdity doctrine is a canon of statutory interpretation holding that a statute's apparent ordinary meaning may be disregarded if the results of its application are (in some sense) ${ }^{8}$ absurd. The conflicts between textualism

4 See SCALIA \& GARNER, supra note 2, at 16-17.

5 See, e.g., Jonathan R. Siegel, The Inexorable Radicalization of Textualism, 158 U. PA. L. REV. 117, 119 (2009).

${ }^{6}$ As Professor Jonathan Molot has noted, two key inquiries shape the debate over the proper scope of the judicial role: (1) the nature of law itself, including "whether judicial leeway is considered narrow or broad" and (2) "prevailing views ... of the constitutional structure and, specifically, on whether judges are viewed as 'faithful agents' or 'coequal partners' of Congress." Jonathan T. Molot, The Rise and Fall of Textualism, 106 ColuM. L. REv. 1, 6 (2006). Professor Molot traces the history of modern textualism through these lenses and describes how modern textualism arose from the desire to minimize judicial leeway in interpretation, coupled with an emphasis on the constitutional structure grounded in the separation of powers, and requiring bicameralism and presentment. See id. at 16, 23-27 ("Indeed, textualism is best understood as one of a series of responses to this newfound appreciation of interpretive leeway and of the judiciary's limited role in the constitutional structure."). I use the phrase "improper judicial lawmaking" to refer to the proper scope of judicial power as conceived of by textualists. Textualism's success is, in large part, attributable to its proponents' ability to persuade others of the legitimacy of this view of the judicial role. See id. at 29-31.

${ }^{7}$ Even the most avowed textualists continue to accept at least some version of the absurdity doctrine. See, e.g., SCAlia \& GARNER, supra note 2, at 234 (including a section on the absurdity doctrine as an appropriate canon of statutory interpretation). The "decline" I have referenced is with respect to the willingness of judges to employ the doctrine, not in their overall acceptance of the doctrine's appropriateness in some instances. This decline is examined in further detail in infra Part I.

8 The precise scope of the absurdity doctrine remains unsettled. See infra Section I.B. 
and at least some iterations of the absurdity doctrine have been well documented in the literature. ${ }^{9}$ Modern judges typically eschew all but the most narrow versions of the absurdity doctrine, requiring a statute's plain meaning to be patently illogical or insensible in order to justify applying the doctrine..$^{10}$ Otherwise, they contend, the judiciary risks overstepping its constitutional limitations by ignoring plain meaning ${ }^{11}$ where it entails an outcome seemingly contrary to the overall statutory purpose or policy. Absurdity's willingness to subvert a statute's clear meaning to avoid an undesirable result obviously clashes with textualism's admonitions regarding the dangers of results-oriented decisionmaking. Yet, as scholars have pointed out, textualism essentially requires some version of the absurdity doctrine in order to avoid truly untenable interpretations or applications of apparently clear statutes.

Textualism's combination of textual primacy and strict limits on the use of the absurdity doctrine significantly constrain judges' discretion to look beyond a statute's text during the interpretive process in order to achieve results thought by a judge to be fair, consistent with statutory purpose, or consistent with legislative intent. However, textualism's success ${ }^{12}$ has had an unintended and potentially counterproductive consequence. Judges, wary of appearing overly "results-oriented" by liberally applying the absurdity doctrine, have seized upon an interpretive rule with broader acceptance that ultimately permits them to achieve the same result: ambiguity.

Once a statute is determined to be ambiguous, even textualists generally consult a much broader range of sources as interpretive aids than would other-

\footnotetext{
9 See infra Part I.

10 See generally SCALIA \& GARNER, supra note 2, at 234.

11 Throughout this article, I use the terms "plain meaning" and "ordinary meaning" interchangeably, consistent with the usage of many modern courts and scholars. See Linda D. Jellum, But That is Absurd! Why Specific Absurdity Undermines Textualism, 76 BrooK. L. REV. 917, 921 n.23 (2011). However, some scholars distinguish between ordinary meaning and plain meaning, typically attributing a search for ordinary meaning to "modern" or "new" textualists, while using plain meaning to distinguish earlier approaches to interpretation that lacked the modern emphasis on context and linguistic use conventions. See, e.g., Lawrence M. Solan, The New Textualists' New Text, 38 LoY. L.A. L. REV. 2027, 2030-32 (2005).

12 Here, I refer to success in terms of influence: "Textualists have spent three decades convincing judges of all political stripes to come along for the ride, and have had enormous success in establishing 'text-first' interpretation as the general norm." See Abbe R. Gluck, Symposium: The Grant in King-Obamacare Subsidies as Textualism's Big Test, SCOTUSBLOG (Nov. 7, 2014, 12:48 PM), http://www.scotusblog.com/2014/11/symposium-the-grant-in-kin g-obamacare-subsidies-as-textualisms-big-test/ [https://perma.cc/VF4E-QAZG]; see also Thomas W. Merrill, Textualism and the Future of the Chevron Doctrine, 72 WASH. U. L.Q. 351, 353-57 (1994) (reviewing existing and offering new contributions to the empirical evidence of textualism's influence and concluding that "there can be no doubt that textualism has asserted a powerful hold over the Supreme Court's statutory interpretation jurisprudence"). While there has been ongoing, strenuous debate over textualism's legitimacy since the doctrine's inception, even its detractors acknowledge its pervasive influence on interpretation in judicial practice and in the academic literature.
} 
wise be permissible. ${ }^{13}$ Thus, if the "hurdle" of ambiguity can be overcome, judges are afforded greater discretion than they would be if hampered by a finding of plain meaning - which, given the current narrow version of the absurdity doctrine, must be applied absent extreme circumstances. The rise of textualism and decline of the absurdity doctrine have created an incentive for judges to find that the language of a statute is ambiguous. By so doing, I will argue, courts are able to achieve results virtually identical to those possible if a judge determined that a statute's meaning was plain and then proceeded to apply some version of the absurdity doctrine. At the same time, by framing their decisions in linguistic, rather than policy considerations, judges minimize the appearance of acting outside the judicial role. Statutory purpose, policy goals, and outcomes can all be considered; contradictory text is supplanted even as its preeminence is exalted. Thus, I refer to this phenomenon as "absurdity in disguise." 14

This article explores how the confluence of modern versions of textualism and the absurdity doctrine contributed to the jurisprudential shift I call absurdity in disguise. In Part I, I describe the uncomfortable fit between textualism and the absurdity doctrine in further detail, outlining their conflicting justifications and policies. In Part II, I describe the phenomenon of absurdity in disguise and explain how the creation of statutory ambiguity enables judges to obtain the same results as if the absurdity doctrine were openly applied. In Part III, I discuss several recent cases in which absurdity in disguise can be observed. The cases involve statutes displaying classic symptoms of absurdity, including statutes that appear to be too broad or too narrow for their applications to be consistent with the statute's likely intended reach.

\section{The Tension Between TeXtuAlism AND THE ABSURDity Doctrine}

Even avowedly textualist judges generally accept at least some version of the absurdity doctrine as an appropriate tool of statutory construction. ${ }^{15}$ However, modern textualists strictly circumscribe the doctrine's use. ${ }^{16}$ Below, in Section I.A, I summarize the basic contours of textualism as an approach to statutory interpretation. Section I.B outlines the absurdity doctrine and the welldocumented conflict between its focus on the results of statutory application and textualist theories of statutory interpretation.

13 See infra Part II.

${ }^{14}$ It should be noted at the outset that the emerging jurisprudential shift discussed here has been noted in recent scholarship and other commentary. However, much of the existing literature identifies this shift with an outright rejection of textualism, or at least a moderation of textualism, in favor of purposivism.

15 See, e.g., SCALIA \& GARNER, supra note 2, at 234 (including a section on the absurdity doctrine as an appropriate canon of statutory interpretation); see also Andrew S. Gold, $A b$ surd Results, Scrivener's Errors, and Statutory Interpretation, 75 U. CiN. L. REV. 25 (2006); John F. Manning, The Absurdity Doctrine, 116 HARV. L. REV. 2387 (2003).

16 See, e.g., Manning, supra note 15. 


\section{A. Textualist Interpretation and Textualism's Rise}

Although certainly not immune from controversy, textualism has had a marked and incontrovertible impact on the theory and practice of statutory interpretation. ${ }^{17}$ Though many of the Supreme Court justices serving after the advent of textualism might reject the textualist label, the Court has made clear that statutory text is to predominate in the search for meaning: "Our task is to construe what Congress has enacted. We begin, as always, with the language of the statute." 18 Textualism's broad influence in the courts has been documented by scholars ${ }^{19}$ and acknowledged by judges themselves: in a 2015 lecture at Harvard Law School, Supreme Court Justice Elena Kagan asserted, “'we're all textualists now." 20

As an approach to statutory interpretation, textualism seeks to determine a text's "ordinary" or "plain" meaning, based on the meaning that a reasonable reader of the language would have ascribed to the text at the time it was enacted into law. ${ }^{21}$ Early textualist doctrine differed markedly from what is commonly described as "modern" or "new" textualism. Specifically, earlier textualists tended to focus on statutes' literal (or, arguably, hyper-literal) meaning. This rigid approach was the root of the idea of "plain meaning." Early courts

17 See, e.g., Molot, supra note 6, at 31; Gluck, supra note 12.

18 Duncan v. Walker, 533 U.S. 167, 172 (2001) (citing Williams v. Taylor, 529 U.S. 420, 431 (2000); Pub. Emp. Ret. Sys. of Ohio v. Betts, 492 U.S. 158, 175 (1989); Watt v. Energy Action Ed. Found., 454 U.S. 151, 162 (1981)). In another case, the Court noted, "As we have repeatedly held, the authoritative statement is the statutory text, not the legislative history or any other extrinsic material." Exxon Mobil Corp. v. Allapattah Servs., Inc., 545 U.S. 546, 568 (2005).

19 See, e.g., Molot, supra note 6, at 3, 32-34 (noting that "textualism has so succeeded in discrediting strong purposivism that it has led even nonadherents to give great weight to statutory text" and citing empirical and anecdotal evidence in support).

20 See Richard M. Re, Justice Kagan on Textualism's Success, PrawfsBlawg (Dec. 7, 2015, 8:00 AM), http://prawfsblawg.blogs.com/prawfsblawg/2015/12/justice-kagan-on-textu alisms-victory.html [https://perma.cc/NW63-7YJ9].

21 See Linda D. Jellum, Mastering Statutory Interpretation 27-28 (2d ed. 2013); SCALIA \& GARnER, supra note 2, at 69; Abner S. Greene, The Missing Step of Textualism, 74 FordHAM L. REV. 1913, 1916 (2006); Manning, supra note 15, at 2396. Textualists will, however, apply technical meanings to statutory terms if the context indicates a word is used as a "term of art." SCALIA \& GARNER, supra note 2, at 76. In Reading Law, Justice Antonin Scalia and Bryan A. Garner's exposition of Justice Scalia's textualism, the authors call this approach the "fair reading method." Id. at 33. Professor John F. Manning, a noted textualist scholar, attributes this conception of plain meaning to "modern" textualism, in contrast with older textual theories claiming that plain meaning referred to situations where statutory text was so clear that interpretation was unnecessary. Manning, supra note 15, at 2396. As Justice Scalia was textualism's most prominent adherent, I describe the ordinary meaning inquiry in the terms he and coauthor Bryan Garner offered in Reading Law. However, textualist interpretation need not conform to this approach, which fixes meaning at the time it was enacted by a legislature. Alternatively, meaning could be ascribed in light of how a reasonable reader would currently interpret statutory text, making meaning "dynamic" as it shifts over time. For a short overview of the controversy over static versus dynamic statutory meaning and citations to relevant literature, see Molot, supra note 6, at $31 \mathrm{n} .133-34$. 
frequently referenced the lack of any need for interpretation where statutory language was plain, viewing application as automatic in those instances. ${ }^{22}$

Modern textualists, in contrast, reject the proposition that interpretation is unnecessary in some instances: "Every application of a text to particular circumstances entails interpretation." ${ }^{23}$ Modern textualists recognize that language is a social construct, drawing on work in philosophy of language originating with Wittgenstein. ${ }^{24}$ Here, the inquiry shifts from the purely definitional to one of conventional and accepted social use. ${ }^{25}$ Moreover, modern textualists emphasize that meaning is shaped by context and the many background assumptions shared by speakers and listeners. ${ }^{26}$ Hence, some scholars employ the term "ordinary meaning" to distinguish the inquiry of modern textualists from that of the earlier "literalist" textualists. ${ }^{27}$ As John Manning has argued, this more holistic, contextual version of textualism significantly reduces the need to resort to fail-safes such as the absurdity doctrine. ${ }^{28}$

Thus, for modern textualists, common understandings and the linguistic usage conventions of statutory terms are of paramount concern. ${ }^{29}$ The approach is portrayed by its proponents as a positive (objective, descriptive) enterprise, grounded in linguistic, social, and historical analysis. ${ }^{30}$ Textualism can be con-

22 See, e.g., Molot, supra note 6, at 34-35.

23 SCALIA \& GARNER, supra note 2 , at 53.

24 Manning, supra note 15, at 2396.

25 See Solan, supra note 11, at 2030 (contrasting "plain meaning, as found in dictionary definitions" with "ordinary meaning," which incorporates the context of a statement while still being able to avoid resort to extratextual sources); see also Richard H. Fallon Jr., The Meaning of Legal "Meaning" and Its Implications for Theories of Legal Interpretation, 82 U. CHI. L. REV. 1235, 1240 (2015).

${ }^{26}$ Disagreements abound over which contextual factors and background assumptions are appropriate for interpreters to consider. See, e.g., Greene, supra note 21.

27 See, e.g., Jellum, supra note 21, at 27-28; Manning, supra note 15, at 2392; Solan, supra note 11.

28 See Manning, supra note 15, at 2455 (arguing that modern textualism retains "substantial means to address many of the problems traditionally handled by the absurdity doctrine" in part because of its emphasis on "the context-dependent meaning of texts" rather than a focus on "literal statutory interpretation") (emphasis in original).

29 Id. at 2396 n. 29.

30 See SCALIA AND GARNER, supra note 2, at 33. Modern textualists generally recognize that interpretation does require the exercise of judgment and may, for instance, require a choice among competing interpretive canons. See, e.g., id. at xxix, 59 (acknowledging that "[t]extualism will not relieve judges of all doubts and misgivings about their interpretations. Judging is inherently difficult, and language notoriously slippery," and that part of the judgment required entails evaluating and choosing among potentially competing canons of construction). However, textualists portray these exercises as grounded in linguistic norms and historical inquiry - with the implication being that these criteria are more objective than judicial policy preferences (or a judge's understanding of a legislature's intentions or policy goals). See Merrill, supra note 12, at 352, 354 (arguing that textualism's “critical assumption is that interpretation should be objective rather than subjective" in contrast with efforts to discern legislative intent, but calling the empirical basis of Justice Scalia's claim of objectivity "doubtful"). The textualist implication that the canons are less manipulable than any other criteria has been criticized for decades. See, e.g., Karl N. Llewellyn, Remarks on the 
trasted with intentionalism, under which a statute's meaning is determined by inquiring into what the legislature intended the statute to mean at the time it was enacted. ${ }^{31} \mathrm{~A}$ third approach, purposivism, focuses on interpreting statutory language consistent with the statute's broader purposes or policy goals in light of the problems the statute was enacted to rectify. ${ }^{32}$

One factor distinguishing the three approaches is the extent to which proponents of each are willing to venture into sources outside of the statutory text to uncover evidence of a statute's meaning. ${ }^{33}$ Textualists tend to be the most restrictive of the three. ${ }^{34}$ For textualists, where a statute is unambiguous, its plain or ordinary meaning is virtually the end of the matter..$^{35}$ Textualists reject the use of legislative history ${ }^{36}$ and other extratextual sources of statutory pur-

Theory of Appellate Decision and the Rules or Canons About How Statutes Are to Be Construed, 3 VAND. L. ReV. 395, 401 (1950). But see Jonathan R. Macey \& Geoffrey P. Miller, The Canons of Statutory Construction and Judicial Preferences, 45 VAND. L. REV. 647, 64748 (1992). Moreover, scholars have argued that even judges considering only text would retain significant discretion. Zeppos, supra note 3, at 1091.

31 See Scalia \& Garner, supra note 2, at xxvii. Professor Linda D. Jellum describes intentionalism as focusing on the "specific intent" of the legislators-i.e. what the legislators had in mind with regard to the particular issue before the court. JELLUM, supra note 21, at 33-34. In contrast, a legislature's "general intent," the legislature's broader goal or overall purpose, is sought by purposivists. Id. at 34 .

32 See Jellum, supra note 21, at 38-41. Purposivism lies at the heart of Hart and Sacks' legal process school and emphasizes the reasonableness and coherence of the body of law as a whole. See generally Henry M. Hart, Jr. \& Albert M. Sacks, The Legal Process: Basic Problems in the Making and Application of Law (William N. Eskridge, Jr. \& Philip P. Frickey eds., 1994).

33 See, e.g., Frank B. Cross, The Significance of Statutory Interpretive Methodologies, 82 Notre Dame L. Rev. 1971, 1973 (2007) (noting that textualism resolves "textual uncertainty[] without relying on extrinsic evidence such as legislative history" and that the theory itself "is broadly accepted as an interpretive methodology, the controversy is over its exclusivism").

34 See generally id.; Jellum, supra note 21, at 33-35; see also Greene, supra note 21, at 1924-25 (describing seven textualist arguments for cutting off "extratextual knowledge" including legislative history).

35 See, e.g., Cross, supra note 33, at 1972 ("Textualists argue that the meaning of a statute can be discerned entirely from the words used in the law under consideration."). The influence that this textualist proposition has had on the Supreme Court as a whole is evident in Justice Thomas' majority opinion in Barnhart v. Sigmon Coal Co., 534 U.S. 438, 461-62 (2002) (citations omitted) (quoting Conn. Nat. Bank v. Germain, 503 U.S. 249, 253-54 (1992)):

Our role is to interpret the language of the statute enacted by Congress. This statute does not contain conflicting provisions or ambiguous language. Nor does it require a narrowing construction or application of any other canon or interpretative tool. "We have stated time and again that courts must presume that a legislature says in a statute what it means and means in a statute what it says there. When the words of a statute are unambiguous, then, this first canon is also the last: "judicial inquiry is complete.",

36 See SCALIA \& GARNER, supra note 2, at 34. "As we have said, in a fair reading, purposeas a constituent of meaning - is to be derived exclusively from a text." Id. Several scholars including Professor Jellum have noted that textualists do not hold this view uniformly; some, more "moderate" textualists would look to legislative history and other extrinsic sources. JELLUM, supra note 21, at 28. However, under what she calls "strict" or "new" textualism, 
pose to supplement or alter clear statutory text. ${ }^{37}$ Modern judges favoring other interpretive approaches frequently begin with the language of a statute, but consider these and other extratextual sources appropriate indicators of meaning to resolve statutory ambiguity. ${ }^{38}$

One primary justification textualists raise in support of their approach is that its focus on ordinary meaning results in a more objective analysis than approaches that seek to determine a legislative body's intentions or purposes. ${ }^{39}$ Textualists argue that ordinary meaning is far less malleable than legislative intent or purpose, meaning that judges are properly more constrained in determining what a statute means and how it applies in a given case. Less malleability means that judges are less able to inject their own policy or outcome preferences into the interpretive inquiry; instead, textualists contend, such matters are reserved to the province of the legislature consistent with separation of powers

and what Scalia and Garner call "pure textualism," these sources are off-limits even where a statute is ambiguous. Id. at 29-30; SCALIA \& GARNER, supra note 2, at xxix. The role of legislative history was traditionally at the crux of arguments among textualists and proponents of other approaches. However, Professor Manning and others have noted the development of new avenues for debate, resulting to some extent in the diminishment of the centrality of the legislative history issue. See, e.g., Molot, supra note 6, at 34-35 (using the example of legislative history to illustrate his argument that the differences between modern textualism and purposivism are exaggerated); see also John F. Manning, Second-Generation Textualism, 98 CAL. L. REV. 1287, 1289-90 (2010) (noting that the major focus of what he refers to as "second-generation textualists" has shifted away from the general question of whether to use legislative history).

37 See Manning, supra note 36, at 1289-90. Professor Frank B. Cross has referred to those textualists who reject the use of extrinsic evidence to supplement statutory language as "strict textualists." See Cross, supra note 33, at 1973. Professor Johnathan T. Molot has described such textualist approaches as "aggressive" textualism. See Molot, supra note 6, at 48. As Professor Jellum has noted, however, textualists do not generally reject all sources outside the statutory text - for instance, textualists widely accept the use of dictionaries and employ a variety of canons of construction to resolve the meaning of statutory terms. JELLUM, supra note 21, at 27.

38 Even some textualists may utilize legislative history when confronted with statutory ambiguity, although in a more circumscribed manner than the traditional use of legislative history to discern a legislature's intent. In his majority opinion in Exxon Mobil Corp. v. Allapattah Servs., Inc., Justice Kennedy noted that the court had "repeatedly held" that "the authoritative statement is the statutory text, not the legislative history or any other extrinsic material. Extrinsic materials have a role in statutory interpretation only to the extent they shed a reliable light on the enacting Legislature's understanding of otherwise ambiguous terms.” Exxon Mobil Corp. v. Allapattah Servs., Inc., 545 U.S. 546, 568 (2005). However, he went on to criticize the use of legislative history based on a variety of textualist arguments and noted the disagreement among the Court regarding whether those problems warranted a blanket refusal to consider legislative history under any circumstances. See id. at 568-69.

39 See, e.g., SCALIA \& GARNER, supra note 2, at 4-10, 17-18. But see William N. Eskridge, Jr., The New Textualism and Normative Canons, 113 Colum. L. REv. 531, 533 (2013) (reviewing Antonin Scalia \& Bryan A. Garner, ReAding Law: The Interpretation of LEGAL TEXTS (2012)) ("Critics of the new textualism claim that its methodology is no more constraining than a methodology that considers legislative history as an interpretive aid."); Greene, supra note 21, at 1928 (arguing that "insisting that judges look just at ordinary meaning of statutory text (even in context), without seeking additional extratextual information about what the text means, can open a gaping hole for judicial willfulness."). 
principles. This separation of powers justification is one of the foremost arguments raised in support of textualism. ${ }^{40}$ Additionally, more objective, predictable outcomes enhance the rule of law. ${ }^{41}$

Further, many textualists challenge the very existence of legislative intentions or coherent legislative purposes to uncover. This contention is grounded in public choice and social choice theories, first proposed by economists to explain and describe legislative behavior and outcomes. ${ }^{42}$ Essentially, these theories portray legislation as the product of compromises among competing interest groups necessary to secure the votes required for a bill's passage. ${ }^{43}$ As a result of these compromises, legislation may not correspond precisely to an overall purpose or policy goal. ${ }^{44}$ The qualities of the legislative process underlie textualists' commitment: even where a statute's ordinary meaning appears anomalous, or inconsistent with the apparent purpose of the statute, textualists nevertheless apply the statute as written.

Thus, textualism's appeal rests largely on its purported ability to restrain judicial discretion in the interpretation of statutes. ${ }^{45}$ Proponents argue that its focus on the ordinary meaning of statutory text minimizes improper judicial lawmaking through the creation of the statutory "gap[s] or imperfection[s]" referenced in the quoted passage at the beginning of this article. ${ }^{46}$ In theory, judg-

40 See Manning, supra note 15 , at 2389 n.6.

41 See SCALIA \& GARNER, supra note 2, at 4, 6, 10, 17-18. " " $[\mathrm{I}] \mathrm{t}$ is not too much to say that the preference for the rule of law over the rule of men depends upon the intellectual integrity of interpretation." Id. at xxix (alteration in original) (quoting GARY L. MCDOwELL, Introduction to Politics and the Constitution: The NAture and Extent of Interpretation vii, vii (1990)).

42 See Manning, supra note 36, at 1292 (discussing interest group theory and social choice theory as two aspects of the broader discipline of public choice); see also Manning, supra note 15 , at $2410-19$.

43 See Manning, supra note 15, at 2410-19.

44 See id.

45 See Zeppos, supra note 3, at 1081 ("By limiting the courts to textual sources, textualism seeks to eliminate value choice in judging: the text alone will dictate a result.").

46 In his relatively early 1992 analysis of textualism as an emerging theory of interpretation, Professor Zeppos summarized the textualist contention as follows:

Textualists argue that the potentially wide array of originalist sources (especially legislative history) gives judges the freedom to justify (and hide) any policy decision. Thus, originalism only encourages judges to stray from their preferably narrow function of ... enforcing the text of laws enacted by the legislature.

Id. at 1086-87. Professor Zeppos defined "originalism"- which he characterized as the dominant interpretive approach until the emergence of various criticisms such as textualism - as a method that "resolves interpretive questions in statutory cases by asking how the enacting Congress would have decided the question." Id. at 1078. Thus, the "originalism" discussed here is consistent with what scholars typically now refer to as intentionalism. See, e.g., JELLUM, supra note 21, at 35. Although some strands of purposivism might emphasize a legislature's actual, subjective purpose (perhaps contrasted with legislative intent as broad or general policy goals rather than intended applications in specific cases), purposivism can also be conceived of as a legal process-type stylized construction of the purpose that could 
es should have less room to supplant a legislature's policy preferences with their own in determining the meaning of statutory text. ${ }^{47}$ Legislative outcomes are a matter of public policy; as such, their consideration is a matter for legislative debate and resolution and not the concern of the courts. Unless, of course, the result of applying a statute's ordinary meaning is absurd. For textualists, the absurdity doctrine provides one of the only justifications for applying a statute in a way that is inconsistent with the statute's ordinary meaning. ${ }^{48}$

\section{B. The Absurdity Doctrine}

The absurdity doctrine permits courts to disregard or modify unambiguous statutory text where the application of its apparent meaning would produce absurd results. ${ }^{49}$ A frequently cited example of absurdity is found in Amalgamated Transit Union Local 1309 v. Laidlaw Transit Service, Inc., in which the Ninth Circuit interpreted the word "less" to mean "more" in a federal statute whose plain language essentially created a waiting period, rather than a deadline, for filing an appeal. ${ }^{50}$ An underlying theme in absurdity cases is that the apparently clear language of a statute can't possibly mean what it says. Some cases, like Amalgamated Transit, involve apparent error or mistake; here, the absurdity doctrine overlaps significantly with the doctrine of scrivener's error. ${ }^{51}$ Another frequent cause of statutory absurdity is statutory vagueness, particular-

be attributed to reasonable legislators pursuing reasonable goals. See Manning, supra note 15 , at 2398-99.

47 See Zeppos, supra note 3, at 1086-87.

48 See generally Ryan D. Doerfler, The Scrivener's Error, 110 Nw. L. REv. 811 (2016) (noting that a related doctrine, scrivener's error, is an additional justification for departing from plain text).

49 Manning, supra note 15, at 2388. In what has become a classic statement on the doctrine, the Supreme Court in United States v. Kirby, 74 U.S. (7 Wall.) 482, 487 (1868) held:

The common sense of man approves the judgment mentioned by Puffendorf, that the Bolognian law which enacted, "that whoever drew blood in the streets should be punished with the utmost severity," did not extend to the surgeon who opened the vein of a person that fell down in the street in a fit. The same common sense accepts the ruling, cited by Plowden, that the statute of 1st Edward II, which enacts that a prisoner who breaks prison shall be guilty of a felony, does not extend to a prisoner who breaks out when the prison is on fire- "for he is not to be hanged because he would not stay to be burnt." And we think that a like common sense will sanction the ruling we make, that the act of Congress which punishes the obstruction or retarding of the passage of the mail, or of its carrier, does not apply to a case of temporary detention of the mail caused by the arrest of the carrier upon an indictment for murder.

Id. at 2388 .

50 Amalgamated Transit Union Local 1309 v. Laidlaw Transit Servs., Inc., 435 F.3d 1140, 1145-46 (9th Cir. 2006).

51 See Manning, supra note 15, at 2459 n.265 (describing the doctrine of scrivener's error as "apparently a form of the absurdity doctrine"); see also Doerfler, supra note 48, at 816 (describing scrivener's errors as cases where "the words of a legislative text diverge from what Congress meant to say"). 
ly overbreadth. ${ }^{52}$ This may be a problem broadly or only with respect to application in specific instances. ${ }^{53}$

The precise scope of the absurdity doctrine remains unsettled. "Cases using or referring to the principle do not define absurdity, nor do they specify the kinds of situations where the principle should be applied." 54 A primary disagreement centers around the question of how absurd a result must be to justify disregarding a statute's ordinary meaning. ${ }^{55}$ Scholars have identified and evaluated various possible conceptions of the doctrine, ranging from "true" absurdity as a matter of formal logic, to absurd in the sense that the result of applying a statute as written offends our sense of justice or fairness. ${ }^{56}$ One prominent textualist scholar defines absurdity as "a version of strong intentionalism" because of a common definition of an absurd result is one "so contrary to perceived social values that Congress could not have 'intended' it." 57

The doctrine's usage has been traced to the very beginnings of the American Republic, ${ }^{58}$ and it "has been one of the few fixed points in the Court's frequently shifting interpretive regimes." 59 In fact, the propriety of the doctrine's use under at least some circumstances is widely accepted, even among judges who otherwise rarely advocate departure from unambiguous text. ${ }^{60}$ The doctrine's scope, however, has vacillated significantly over time. The seminal case

52 A classic example of statutory overbreadth leading to an arguably absurd result is the case of Green v. Bock Laundry Mach. Co., 490 U.S. 504, 527 (1989). In that case, a Federal Rule of Evidence purportedly applied to all "defendants," not just civil defendants, which would have prioritized civil defendants over civil plaintiffs in application, raising questions of constitutionality. See id. at 509-11. In Justice Scalia's concurring opinion, he specifically invoked the absurdity doctrine: "We are confronted here with a statute which, if interpreted literally, produces an absurd, and perhaps unconstitutional result." Id. at 527 (Scalia, J., concurring). He found that interpreting "defendant" more narrowly to mean "criminal defendant" was an acceptable interpretation that did the "least violence" to the text. Id. at 529.

53 Professor Jellum described both Green and Holy Trinity Church as cases involving "general absurdity," i.e. ones which are "absurd regardless of the particular situation before the court." Jellum, supra note 11, at 930. Both cases involve instances of arguable statutory overbreadth. On the other hand, some cases she describes as instances of "specific absurdity"-i.e. those where "the applicable statutes are perfectly logical in the abstract, but [absurd when] applied to the specific facts of the case before the court"- also involve arguable overbreadth. Id. at 932 . For instance, a statute prohibiting escapes from prison is generally uncontroversial, but becomes problematic when a prisoner escapes in order to save himself from a fire. The statute in that specific case seems broader than its intended reach. See id.

${ }^{54}$ See Veronica M. Dougherty, Absurdity and the Limits of Literalism: Defining the Absurd Result Principle in Statutory Interpretation, 44 AM. U. L. REV. 127, 128 (1994).

55 See id.

56 See id. at $140-41,150-51$.

57 Manning, supra note 15, at 2390; accord Gold, supra note 15, at 25-27.

58 See generally Manning, supra note 15.

59 See id. at 2389.

${ }^{60}$ See id. at 2388-89; see also Dougherty, supra note 54, at 128. 
on the absurdity doctrine, the oft-maligned ${ }^{61}$ Holy Trinity Church v. United States,${ }^{62}$ perhaps marks the broadest conception of the doctrine. ${ }^{63}$ In that case, the Supreme Court interpreted a provision of the Alien Contract Labor Act prohibiting bringing people from other countries to the United States "to perform labor or service of any kind" not to apply to the services of a pastor brought into the country by the church. ${ }^{64}$ The Court (in)famously ruled that although the pastor's services fell within the letter of the law, "a thing may be within the letter of the statute and yet not within the statute, because not within its spirit nor within the intention of its makers." 65

No matter one's view of the wisdom of a statute broadly prohibiting the importation of "laborers," it is clear that the statute's plain meaning does not rise to the level of absurdity that textualists would require before disregarding the text. The version of the absurdity doctrine accepted by Justice Scalia would require both that the claimed absurdity "consist of a disposition that no reasonable person could intend" and that it "be reparable by changing or supplying a particular word or phrase whose inclusion or omission was obviously a technical or ministerial error." ${ }^{66}$ Not only is the hurdle envisioned "very high," the doctrine as envisioned here would categorically refuse to address "substantive errors" arising as a result of the application of a statute to particular circumstances. ${ }^{67}$

Notably, Holy Trinity Church is alternatively described as exemplifying the high point of the absurdity doctrine and the high point of purposivist interpretation more generally. ${ }^{68}$ This conceptual overlap is especially telling in light of modern purposivists' reluctance to subvert the import of apparently clear statutory text in favor of the purpose of the statute, even where the two directly conflict ${ }^{69}$ Instead, modern purposivists generally delve into purpose only to clarify statutory ambiguity. This limitation, another outgrowth of textualism's rise in popularity, has contributed to the erection of the ambiguity "hurdle" that stands

61 See Pub. Citizen v. United States Dep't of Justice, 491 U.S. 440, 472-74 (1989) (Kennedy, J., concurring); see also Carol Chomsky, Unlocking the Mysteries of Holy Trinity: Spirit, Letter, and History in Statutory Interpretation, 100 COLUM. L. REv. 901, 905-06 (2000).

62 Holy Trinity Church v. United States, 143 U.S. 457 (1892).

63 See Jellum, supra note 11, at 925-26 (noting that Holy Trinity Church "expanded Kirby's narrow absurdity doctrine").

${ }^{64}$ Holy Trinity Church, 143 U.S. at 458.

65 Id. at 459.

66 SCALIA \& GARNER, supra note 2, at 237-38.

67 See $i d$. In that sense, the doctrine here is effectively indistinguishable from the related "scrivener's error" canon.

68 See Manning, supra note 15, at 2403 (calling Holy Trinity Church one of the "classic[]," "leading," and "most influential" absurdity cases, while describing the absurdity doctrine as a version of "strong intentionalism"); Molot, supra note 6, at 14 (describing the case as "[t]he most famous, influential example of the Court's bold purposivism in federal statutory interpretation during [the] period ....").

69 See John F. Manning, The New Purposivism, 2011 Sup. CT. Rev. 113, 113 (2011). 
in the way of fuller purposive or results-oriented inquiries and led to the phenomenon of ambiguity in disguise.

As noted, in contrast to Holy Trinity Church, more recent opinions of the Court have endorsed substantially narrower iterations of the absurdity doctrine. This modern conception of the absurdity doctrine goes beyond individual, avowedly textualist justices such as Justice Scalia. In 2011, tracing the history of the doctrine's use, Professor Linda Jellum noted that the Supreme Court had "explicitly relied on the absurdity doctrine only five times" since $1989 .{ }^{70}$ In a majority opinion, the Supreme Court has described the doctrine as one to be used only "rarely" and as a last resort. ${ }^{71}$ The Court has ruled that even the possibility of an "unintentional drafting gap" is insufficient to warrant judicial correction; correction is the province of Congress in cases where an admittedly "anomalous" result "may seem odd, but . . . is not absurd." "It is not enough that applying the unambiguous language lead to "counter-intuitive" results to warrant the invocation of the absurdity doctrine. ${ }^{73}$

The Court's hesitancy to employ the absurdity doctrine to disregard a statute's plain language is likely attributable to the rise of textualism as an approach to statutory interpretation. ${ }^{74}$ This is unsurprising given the absurdity doctrine's close relationship with purposivism - to reject one is, in many respects, to reject the other. The following section identifies in further detail the friction between textualism and the absurdity doctrine.

\section{Textualism and the Absurdity Doctrine: In Tension at Best, Irreconcilable at Worst}

To reiterate, textualists maintain that their approach minimizes judicial policymaking; textualists focus solely on what a statute, as written, means, leaving the question of whether its application is desirable to the domain of the legislature. Whether the outcome of applying a statute is "desirable" is, in many respects, a policy question of whether a statute should govern in certain circumstances. Averring that such policy decisions are the province of legislatures rather than courts, textualists invoke separation of powers arguments to require that, at least insofar as statutes are clear, they must be interpreted and applied as

70 Jellum, supra note 11 , at 926.

71 See id. at 926-27 (quoting Barnhart v. Sigmon Coal Co., 534 U.S. 438, 441 (2002)).

72 Exxon Mobil Corp. v. Allapattah Servs., Inc., 545 U.S. 546, 565 (2005). The Court also noted in its holding that:

This is not a case where one can plausibly say that concerned legislators might not have realized the possible effect of the text they were adopting. Certainly, any competent legislative aide who studied the matter would have flagged this issue if it were a matter of importance to his or her boss, especially in light of the Subcommittee Working Paper. There are any number of reasons why legislators did not spend more time arguing over [the statute], none of which are relevant to our interpretation of what the words of the statute mean.

Id. at 571 .

73 See Barnhart v. Sigmon Coal Co., 534 U.S. 438, 459 (2002).

74 See Manning, supra note 69, at 113-14. 
written. The desirability of the results of applying statutes in specific cases is to play no role in determining their meanings. Though modern textualism considers context, in this sense a strict separation is attempted between what statutory language means and its import in application.

Herein lies the root of the conflict between textualism and the absurdity doctrine. ${ }^{75}$ The absurdity doctrine is avowedly results-oriented; textualists generally reject consideration of such results as constitutionally problematic. Yet even the most committed textualists acknowledge that results cannot be ignored in every instance. As several scholars have thoroughly documented, the absurdity doctrine provides a sort of "fail-safe" for textualists in the event that their commitment to the text becomes unacceptably unpalatable. But, as John Manning notes, "[i]f modern textualists perceive their methodology to be workable only because of the availability of the absurdity doctrine, then one must question the conceptual foundations of textualism itself." "76 Linda Jellum made this tension the focus of an entire article, contending that "absurdity and textualism are simply incompatible; indeed, the absurdity doctrine undermines the very foundation of textualism." 77 William Eskridge has made the point that if the absurdity doctrine is acceptable to textualists, there is no sound justification for adhering to ordinary meaning even where a result seems merely unreasonable, as opposed to patently absurd. ${ }^{78}$

Despite the apparent contradictions, however, early textualists evidently applied the absurdity doctrine frequently — in tracing the doctrine's development, Professor Jellum notes that it "was commonly used up until the 1940s as a way to temper the sometimes harsh effects of the plain meaning canon in its literalist formulation." ${ }^{\prime 79}$ In a following intentionalist period, Professor Jellum notes that "the plain meaning canon fell from favor; and thus, the absurdity doctrine faded briefly into obscurity." 80 The advent of modern textualismwhich scholars frequently trace to at or near the time of Justice Scalia's appointment to the Supreme Court ${ }^{81}$ — renewed the utility of the absurdity doctrine. ${ }^{82}$ Yet, the modern Court has been far less willing to employ it, at the same

75 And perhaps, as noted above, between textualism and "strong" (i.e., not modern) purposivism.

76 Manning, supra note 15, at 2392.

77 Jellum, supra note 11, at 919.

78 See Manning, supra note 15, at 2411 (citing William N. Eskridge, JR., DynamiC STATUTORY INTERPRETATION 26-27 (1994)).

79 Jellum, supra note 11, at 926.

80 Id.

81 See id. (tracing modern textualism to 1986, when Justice Scalia was appointed); Richard J. Pierce, Jr., The Supreme Court's New Hypertextualism: An Invitation to Cacophony and Incoherence in the Administrative State, 95 Colum. L. REv. 749, 750 (1995) ("During the period 1982-1992, the Court decreased its use of intentionalism and increased its use of textualism.").

82 See Jellum, supra note 11, at 926; Pierce, supra note 81, at 750. 
time that many of the justices feel obligated to pay homage to ordinary meaning. ${ }^{83}$

This is, no doubt, attributable in part to the important modifications to the old plain meaning rule that modern textualists have made; the ordinary meaning inquiry is fuller and richer than the surface glance that characterized plain meaning. Although the modern emphasis on social usage conventions is viewed by textualists as an objective inquiry, none would deny that it is an inquirythe interpretive process is not automatic. Even unambiguous texts are viewed as requiring analysis, placement within context, and deliberation. To the extent the absurdity doctrine was required to remedy "hyper-literal" interpretations, it may simply be less needed under modern textualism.

On the other hand, another explanation for the Court's reluctance to rely on absurdity is likely the justices' intuition (consistent with the arguments made by Professors Manning and Jellum, among others) that textualism ${ }^{84}$ itself is undermined by the need for the absurdity doctrine and the doctrine's application. Many of the core justifications underlying modern textualism seem to entail an extremely high threshold for absurdity in order to justify disregarding a statute's ordinary meaning. In particular, the arguments based on public and social choice theory described in the previous section indicate that judges should be extremely wary of potentially undermining the policy decisions of the legislature. Public and social choice theories theoretically normalize legislative outcomes that are "merely" odd, anomalous, ill-conceived, illogical, not ideal, or even silly. Oddities may not be simple mistakes; instead, they might represent a hard-won legislative compromise or crucial negotiated point. And, if the statutory scheme or body of law as a whole is not quite neat or coherent, that's to be expected, too-after all, we can't expect rational outcomes in collective decision-making in the first place. ${ }^{85}$

Further, many of the formalist underpinnings of textualism come into play at this point to counsel against judicial "correction" of less-than-absurd results, through, for example, the imposition of legal process-type assumptions of "rea-

83 See Pierce, supra note 81 , at 752.

${ }^{84}$ Here, "textualism" is used largely as a shorthand and not to suggest that most Supreme Court justices would self-identify as textualist or be overly concerned about undermining "textualism" itself. Instead, the point here is that despite the controversy it engenders, textualism has notably influenced the Supreme Court's approach to statutory interpretation. Much of this influence is likely due to concerns over avoiding excess judicial discretion, maintaining separation of powers, and the like. Additionally, public and social choice theories, along with the law and economics discipline broadly, have influenced the courts both jointly with and independently of textualism. Cf. Thomas W. Merrill, Capture Theory and the Courts: 1967-1983, 72 CHI.-Kent L. REV. 1039, 1039-40 (1997) (tracing the influence of interest group theory and public choice theory in Supreme Court decision-making in a variety of agency contexts). All of these factors contribute to both textualism's rise and absurdity's decline.

85 For John Manning's discussion of social choice theory see Manning, supra note 15, at 2412-19. 
sonable persons pursuing reasonable purposes, reasonably." 86 Textualists argue that the constitutional requirements of bicameralism and presentment preclude judges from revising the text that was actually produced by Congress and approved by both Congress and the President. And, again, once it is accepted that the legislative process may inherently produce anomalies - that these may be "intended" (in some sense) ${ }^{87}$ rather than the result of inadequate foresight or ineffective expression - commitment to legislative supremacy ${ }^{88}$ seems to mandate deference to the bargains struck.

Finally, the absurdity doctrine's conceptual closeness with purposivism offers insight into the inverse paths of textualism and absurdity. The unabashed consideration of outcomes in light of an enacting legislature's likely (or perceived) purposes or goals (outside of those that are textually evident) is antithetical to textualist methods. For textualists, the danger is too great that in attempting to discern the legislature's purpose and interpret statutes in accordance with it, the judge's personal views of the ideal policy outcomes will ultimately prevail. Interpretation essentially takes place in one direction: the statutory text is to shape the outcome of applying it in a given case. Purposivists do not interpret rigidly in one direction. ${ }^{89}$ For purposivists, an outcome that is odd or counterintuitive in relation to a purpose the statute seems intended to serve may indicate that a judge has misconstrued the statute and should reexamine the text. Notably, this broad version of purposivism does not require an ambiguity finding, either ex ante or ex post. The consideration of outcome in light of purpose is viewed as a proper inquiry into meaning regardless of the existence of ambiguity. ${ }^{90}$ The absurdity doctrine echoes the two-direction fea-

86 See generally HART \& SACKS, supra note 32, at 1374-78; see also JELLUM, supra note 21, at $38-42$.

87 Joseph Raz offered one conception of a more generalized legislative intent that depends not on the specific, subjective intentions of legislators, but rather is based on the assumption that the legislators broadly intended to enact the law as delineated by the statutory text. He essentially argued this minimal sort of intent is necessary in order to establish the authority of law. See Manning, supra note 15, at 2457 n.258.

${ }^{88}$ Many debates among statutory interpretation "camps" revolve around which approach best upholds the principle of legislative supremacy in the enterprise of making law. See, e.g., John F. Manning, What Divides Textualists from Purposivists?, 106 CoLUM. L. Rev. 70, 91 (2006).

${ }^{89}$ Molot, supra note 6, at 36-37 (arguing that "[t]extualists accuse purposivists of continuing to look to context after they have arrived at a clear textual meaning," but contending that this "alleged distinction ... is not meaningful.").

${ }^{90}$ By way of analogy using textualist terms, consider the textualist distinction between "determining the ordinary meaning of the text" on the one hand and "resolving ambiguity" on the other: some tools of construction are appropriate at either or both phases, while others become permissible only if ambiguity is found ex ante and a judge must proceed to resolve it. One key difference between textualism and purposivism may be that purposivists do not draw this conceptual distinction, or at least find the distinction less significant in practice. Even for textualists, the nature and scope of these two stages is not especially welldeveloped in the literature, and occasionally the two phases are conflated. However, there is ample support for the existence of a division given that the use of certain canons and other interpretive tools is consistently described as proper only to resolve ambiguous statues, while 
ture of purposivist interpretation, effectively eliminating the distinction between clear versus ambiguous text by treating clear text as if it were ambiguous. Thus, to the extent textualism relies on the absurdity doctrine as a fail-safe, it admits the superiority of an opposing interpretive approach..$^{91}$

The Supreme Court's current conception of the absurdity doctrine shares little in common with Holy Trinity Church's unabashed elevation of the spirit of the law over its text. As the Supreme Court's interpretive jurisprudence increasingly incorporated textualist principles, its willingness to invoke the absurdity doctrine likewise decreased. In the absence of extreme circumstances, textualist-influenced courts cannot overtly invoke the modern absurdity doctrine either to avoid interpretations of unambiguous statutory text that seem inconsistent with the statute's broad purpose or goals, or to avoid applying a statute according to its clear terms where the result seems merely incongruous, unexpected, or just plain odd..$^{92}$

\section{ABSURdity In Disguise: The Role OF AMBIGUity}

The increasing acceptance of textualist interpretive approaches has curtailed the acceptable uses of the absurdity doctrine. Yet, regardless of what method of statutory interpretation judges employ, they are inevitably faced with the task of interpreting and applying statutory text to resolve actual disputes with significant legal and policy consequences. The implications of doing so cannot be entirely lost on judges, even for those who make every effort to remain apolitical and faithful to the judicial role. Whether a judge intentionally or unconsciously seeks to disguise a results-oriented interpretation, the results of particular interpretations have the potential to impact interpretive decisions. Given textualists' frequent admonition that their theory is necessary in part because of the concern that judges will otherwise fail to restrain the impulse to interpret statutes to achieve a desired result, it would certainly be difficult for textualists to contend that this temptation does not exist.

The confluence of this inevitable temptation and the restrictions of textualist doctrine has created the somewhat perverse incentive for judges to conceal or obfuscate outcome-sensitive reasoning as the basis for judicial decisions. Less-accepted doctrines, such as broad versions of the absurdity doctrine, must

at the same time the determination of ordinary meaning is described as a process of contextual analysis and may include sources of meaning such as dictionaries even where text is ultimately determined to be unambiguous. Unlike the old plain meaning rule, then, a statute's meaning need not be immediately and automatically crystal clear in order to be unambiguous. Thus, the potential for two separate inquiries to occur (i.e., an unsuccessful initial attempt to determine the text's ordinary meaning resulting in an ambiguity finding, followed by the resolution of the ambiguity) is implicit in textualist doctrine.

91 See Jellum, supra note 11, at 938.

92 And, because even modern purposivists purport to prioritize clear text, taking an explicitly non-textualist approach is no longer a viable option either, short of significantly overhauling a significant amount of language in the Supreme Court's interpretation jurisprudence emphasizing the primacy of statutory text. 
be pursued under cover of more widely accepted interpretive doctrines. Here, then, is the root of absurdity in disguise. Whether consciously or not, judges have had to seize on less controversial rules of interpretation as vehicles for pursuing certain results in particular cases. Ambiguity fits the bill. ${ }^{93}$

An ambiguity finding opens the door to a wealth of interpretive tools that would not be available without it. Crucially, all textualists-even strict textualists - authorize the use of a much broader array of sources of meaning in cases where the text is found to be ambiguous. ${ }^{94}$ While "strict" textualists, like Justice Scalia, would continue to eschew legislative history even to resolve ambiguity, other textualists would permit its use. ${ }^{95}$ But other sources are permitted by even "pure" textualists. For instance, while Justice Scalia would not permit the use of headings and titles in statutes to override an apparently conflicting, but clear provision in the statutory text, he would permit the use of headings and titles to clarify ambiguous statutory text. ${ }^{96}$ Other examples abound, including not only a variety of text-based canons, but also substantive canons like the constitutional avoidance canon ${ }^{97}$ and the rule of lenity. ${ }^{98}$

93 Even with modern textualists' emphasis on ordinary meaning in context, instances still arise where either multiple reasonable possibilities exist as to meaning, or the meaning is simply not clear without further information. As noted, even modern textualists' holistic, contextual prescriptions for the determination of ordinary meaning do not preclude ambiguity findings in some instances. Thus, the question of ambiguity's existence is uncontroversial. See Molot, supra note 6, at 35 (noting that "even the most committed textualists have openly acknowledged that text can be ambiguous ..."). However, the frequency of ambiguity findings by textualists versus purposivists has been criticized. See Merrill supra note 12, at 354 (arguing that textualist judges are more likely than other judges to determine that statutes are unambiguous and that this tendency is excessive and problematic).

94 See Koons Buick Pontiac GMC, Inc. v. Nigh, 543 U.S. 50, 67 (2004) (Thomas, J., concurring) ("If the text were clear, resort to anything else would be unwarranted ... But I agree with the Court that [it] is ambiguous ...."); see also JELLUM, supra note 21, at 28-29.

95 See Jellum, supra note 21, at 27-30.

96 SCALIA \& GARNER, supra note 2, at 221-22.

97 Professor Jellum describes the constitutional avoidance canon as another method, along with the absurdity doctrine, of avoiding the ordinary meaning of statutory text. JELLUM, supra note 21, at 96-98. However, the avoidance doctrine was traditionally invoked as a way of resolving preexisting ambiguity. Id. at 96. Another scholar, Eric S. Fish, has contrasted the two conceptions and identified examples in recent caselaw. See Eric S. Fish, Constitutional Avoidance as Interpretation and as Remedy, 114 Мich. L. Rev. 1275, 1275-78 (2016). He describes Jellum's conception as a contemporary use of the avoidance doctrine that more closely resembles remedy, rather than an interpretive canon, and defends its use as a separate doctrine from the original canon. See id. at 1279-80. I contend that this "contemporary" avoidance is but one iteration of the broader phenomenon of absurdity in disguise. After all, that Congress might enact a law of questionable constitutionality is not narrowly absurd in the sense of being truly illogical or inconceivable-meaning that it cannot be overtly brought under the now-narrowed absurdity doctrine. Further, the proposition that Congress could not have intended to violate the constitution is not coterminous with the proposition that Congress could not have intended to enact the law that it did in the language that it used - and textualists, who reject considerations of the results of applying a statute, would be concerned only with the latter proposition even in absurdity cases. According to Justice Scalia-esque textualists, the proper inquiry would focus on whether it is absurd to imagine that Congress intended to enact the very language that it did. Yet, at the same time, 
An important point to emphasize is that ambiguity opens the door to additional sources of statutory meaning when the ambiguity finding is made ex ante (i.e., at the outset of the interpretive process). Traditionally, if an ambiguity finding is not made at the outset, sources beyond ordinary meaning cannot be consulted. 99 "Many tenets of statutory interpretation take a peculiar form. They allow consideration of outside information-legislative history, practical consequences, the statute's title, etc.- -but only if the statute's text is unclear or ambiguous." 100

In contrast, as described in the previous section, the absurdity doctrine essentially allows a court to treat clear text $a$ s if it were ambiguous, opening the door to a broad array of interpretive tools that would otherwise not be available. When the absurdity doctrine is applied, a court may adopt a less natural reading of the statute that avoids the problematic results of applying the statute's most obvious or ordinary meaning. This may involve narrowing or qualifying overbroad terms in a statute, creating exceptions, extending the statute beyond its apparent reach, or adopting an uncommon or unusual usage as the definition of a statutory term (among other things). Whether statutory text is actually ambiguous or merely treated as such, the constraints of the plain meaning canon are removed: ipso facto, there is no plain meaning to apply.

For textualists, ambiguity is less controversial than the absurdity doctrine for a variety of reasons. Perhaps most significantly, ambiguity is viewed as a purely linguistic phenomenon rather than as a question of policy preference. Ambiguity can even be differentiated from textual canons of interpretation like the rule against surplusage, which instructs that wherever possible statutes

it would certainly strike many as more than odd to imagine that Congress intended to enact an unconstitutional law. This tension reflects the continuum of definitions of absurdity-an unconstitutional ordinary meaning is appropriately conceptualized as one type of absurdity falling below the threshold necessary to fall within the modern absurdity doctrine's narrow reach.

98 SCALIA \& GARNER, supra note 2, at 296-302.

99 For instance, see the Supreme Court's decision in Exxon Mobil Corp. v. Allapattah Servs., Inc:

The proponents of the alternative view of $\S 1367$ insist that the statute is at least ambiguous and that we should look to other interpretive tools, including the legislative history of $\S 1367$, which supposedly demonstrate Congress did not intend $\S 1367$ to overrule Zahn. We can reject this argument at the very outset simply because $\S 1367$ is not ambiguous.

Exxon Mobil Corp. v. Allapattah Servs., Inc., 545 U.S. 546, 567 (2005). The implication here is that without the ambiguity finding in advance, it would be inappropriate to consider legislative history. Whatever might be found in the legislative history cannot be permitted to impact the interpretation of clear text. See Koons Buick Pontiac GMC, Inc. v. Nigh, 543 U.S. 50, 67 (2004) (Thomas, J., concurring) (citations omitted) ("If the text in this case were clear, resort to anything else would be unwarranted. But I agree with the Court that [it] is ambiguous . . .."); JELLUM, supra note 21, at 28.

100 William Baude \& Ryan D. Doerfler, The (Not So) Plain Meaning Rule, 84 U. CHI. L. REV. 539, 540 (2017). 
should be interpreted to avoid rendering a provision inoperative. ${ }^{101}$ Whereas the latter doctrine is justified by the claim that it reflects typical usage conventions employed by average speakers (here, avoiding redundancy), ambiguity effectively justifies the need to resolve it by its very existence. Any problem with the clarity of statutory language must necessarily be resolved as a part of the process of interpretation. Otherwise, by definition, there is no meaning-plain, ordinary, or in any other sense- to apply. Whatever controversy exists over what interpretation properly entails, resolving ambiguity is indisputably a necessary component.

This insight, although self-evident, is actually quite significant. Ambiguity is invariably, and for the most part uncontrovertibly, viewed as interpretation in a positive sense. In other words, even the use of textual canons that purport to reflect typical usage conventions is normative in the sense that to employ them as some textualists do is to assert, inter alia, (1) that the ordinary meaning of text based on general usage constitutes the meaning of the text in the sense that is relevant for statutory interpretation, (2) that the textual canons accurately reflect usage conventions in the relevant linguistic community (or that they do so frequently enough to be useful), and so on. ${ }^{102}$ Ambiguity is least associated with judicial "construction"- the view of some scholars of interpretation that a separate process beyond interpretation exists in which judges must venture beyond linguistic analysis in order to give meaning to statutory text. ${ }^{103}$ The concept, and even the existence, of a separate step of statutory "construction" has been hotly debated, likely because it suggests a degree of judicial lawmaking. ${ }^{104}$ Interpretation, on the other hand, is more broadly viewed as fully within the proper judicial role. Thus, ambiguity fits most comfortably within the limited scope of judicial decision-making that textualist judges espouse and with which judges in general are likely most comfortable.

101 See Advocate Health Care Network v. Stapleton, 137 S. Ct. 1652, 1659 (2017) (explaining that the surplusage canon presumes "that each word Congress uses is there for a reason."). These canons, too, are closely related to ambiguity in that they may be employed to resolve ambiguous statutory text. In fact, authority can be found for the proposition that canons such as these are only to be utilized once statutory text has been found to be ambiguous. On the other hand, these canons are sometimes used without an explicit (and sometimes even without an implicit) finding of ambiguity; instead, it appears as though they are being employed as part of the determination of the ordinary meaning of text. Given that ordinary meaning is largely by the ordinary use of terms found in statutes, the latter approach makes some sense for linguistic canons such as those mentioned here.

102 Even proponents of the canons' use acknowledge that they will conflict in some instances, necessitating a normative judgment as to which should be employed. $C f$. SCALIA \& GARNER, supra note 2, at 33 (indicating how some canons only apply to ambiguous terms and others to vague terms).

103 See, e.g., Lawrence B. Solum, The Interpretation-Construction Distinction, 27 Const. COMMENT. 95, 95-96 (2010).

104 See, e.g., SCALIA \& GARNER, supra note 2, at 13-14. 
Further, because ambiguity is viewed as a problem inherent in the text itself, ${ }^{105}$ the source of the problem is the unclear or inadequate expression by the legislature which drafted the text. Placing the source of the problem squarely on the legislature's expression contributes to the perception of ambiguity as solely a textual, as opposed to "substantive" doctrine. Unlike the absurdity doctrine, the justification for employing tools to resolve ambiguity is nonconsequentialist. ${ }^{106}$ Here, perhaps, is one of the key distinctions between ambiguity and absurdity (and a key explanation for why the former canon is far less controversial): to invoke the absurdity doctrine, a judge must consider the result of applying clear statutory text and determine that this result is a problem. The problem arises during the fundamentally judicial process of interpreting statutes and applying them in specific cases. In cases involving ambiguity, judges can argue that they cannot even begin to engage in this judicial process without first resolving the problem of unclear drafting, which arose as part of the legislative process. It is far easier to avoid the charge that judges inject their own policy preferences into the interpretive process when the problem at issue is viewed as one originating outside the judicial process, but simultaneously squarely within the judicial role to resolve.

The perception of ambiguity as solely a function of language, and not dependent on legislative policy choices ${ }^{107}$ or judicial policy preferences, lends courts' efforts to resolve it an air of objectivity that contributes significantly to its broad acceptance within the judicial role. On the one hand, it would be difficult to imagine a scholar of linguistics contending that the determination of meaning is a simple, purely objective affair. Linguistics, like any scholarly field, is rife with controversy over a number of questions involving the meaning of language. ${ }^{108}$ That said, the conventional (or "lay") use of linguistic ter-

105 The thesis of this paper is that in many situations where ambiguity is found, it is actually "created" by the problematic result of applying text that is, in actuality, clear. I also note later in this section that the conflation of the concepts of ambiguity and vagueness frequently results in ambiguity findings where true ambiguity is not present. The proposition here is thus intended to express a common perception of ambiguity that contributes to its broad acceptance and "reputation" for objectivity; I do not assert this as a fact about ambiguity findings in practice.

106 Of course, any interpretive method or tool is consequentialist in the sense that the interpretive enterprise as a whole seeks to determine the meaning of statutory text. However, ambiguity need not (but, of course, may) be resolved with an eye toward the outcome of the decision. In contrast, the absurdity doctrine is implicated solely because of an undesirable outcome and applied with the explicit goal of avoiding that outcome in favor of a preferred one.

107 True ambiguity is almost always the result of carelessness or inattention. It is rarely intentional - though there are certainly instances of statutory or contractual ambiguity in which each side, fully aware of the ambiguity, embraces it in the hope or belief that its version of meaning will ultimately prevail.

SCALIA \& GARNER, supra note 2, at 32.

108 See, e.g., LAURIE BAUER, BEginNing Linguistics 11-12 (2012). As one simple example, the word "happen" has two meanings: "Did you happen to see the accident happen?" Id. at 
minology such as "semantics" suggests a technical, literal meaning. While many prominent textualists, for instance, reject the characterization of their approach as overly literal (or semantic in its most negative, lay connotation), they do benefit in a way from this perception because it suggests a relatively objective, almost scientific approach to the determination of statutory meaning.

Moreover, typical examples of linguistic ambiguity given in the statutory interpretation context include simple examples based on homonymous words whose meanings are easily resolved within proper context. ${ }^{109}$ This may give the (likely misleading) impression that resolving ambiguity is simply a matter of examining the context of a term to determine the sense in which it is used. While most textualists would likely agree that, in practice, ambiguity is not necessarily so simplistic, the frequent use of simple examples to illustrate the concept is another factor that contributes to the perception that ambiguity is purely a matter of linguistics or language-implying its existence is unrelated to policy judgments or outcome considerations. ${ }^{110}$

Another explanation for the appeal of ambiguity is its malleability. The problem of defining statutory ambiguity has been widely addressed in the literature. ${ }^{111}$ As a number of scholars have noted, ambiguity could refer only to situations where statutory text suggests two (or more) "equally plausible" meanings. ${ }^{12}$ This would be a more significant hurdle for an ambiguity finding than, for instance, a standard providing that a statute is ambiguous if reasonable people could disagree as to its meaning. ${ }^{113}$ A very broad definition of ambiguity could provide that a statute is ambiguous if it has two or more possible meanings. ${ }^{114}$ And, of course, courts may determine a statute is ambiguous without explicitly offering a definition of ambiguity. Moreover, the difficulty of drawing the line between clear and ambiguous text is not confined to one interpre-

13. Linguists debate whether "happen" is one word with two meanings, exhibiting the quality of polysemy, or two words that are homonyms. See id. at 14.

109 Take, for instance, the common example of "bay," which could mean a horse or a geographic feature depending on the context. See Bay, MERriam-Webster OnLine Dictionary, https://www.merriam-webster.com/dictionary/bay [https://perma.cc/68TS-DC6K] (last visited Jan. 21, 2019).

110 The thesis of this paper is that ambiguity, in practice, has been found to exist as a result of policy preferences or considerations regarding the outcome of applying apparently clear statutory language. The proposition here is simply that the common perception of ambiguity is that it is not the result of such preferences, and is purely a linguistic phenomenon.

111 See Brett M. Kavanaugh, Fixing Statutory Interpretation, 129 HARV. L. REV. 2118, 2134-40 (2016) (reviewing Robert A. KatzManN, Judging Statutes (2014)); Lawrence M. Solan, Pernicious Ambiguity in Contracts and Statutes, 79 CHI.-KENT L. REV. 859 (2004) ("[T] he concept of ambiguity is itself perniciously ambiguous. People do not always use the term in the same way, and the differences often appear to go unnoticed.").

112 See, e.g., Jellum, supra note 21, at 88 (quoting Linda D. JELlum \& David C. HriciK, Modern Statutory Interpretation: Problems, Theories, and LaWyering Strategies 94 (2d ed. 2009)).

113 See id.

114 See id. at 87. 
tive approach and does not appear to impact judicial decision-making within interpretive approaches in a consistent way. ${ }^{115}$

Further, ambiguity is amenable to the exercise of judicial discretion because of its frequent conflation with the related concepts of vagueness. While legal scholars and philosophers of language regularly distinguish the concepts of ambiguity and vagueness, this line is not commonly drawn in judicial opinions. ${ }^{116}$ While ambiguity refers to a situation where language is subject to varying interpretations because it can be understood in two or more different senses, vagueness occurs where the scope or extent of what a term refers to is unclear or indeterminate. ${ }^{117}$ While an ambiguous term could arguably denote two completely different things - "bay" as a horse or as a water feature - a vague term typically denotes similar things, but to an unclear extent. ${ }^{118}$ Thus, in Hart's classic problem of the prohibition of vehicles in the park, the term vehicles may or may not include bicycles, skateboards, or strollers. ${ }^{119}$ This factor may be one of the most significant in terms of explaining the phenomenon of ambiguity in disguise: the ability to invoke policy to narrow statutory text or to create exceptions without invoking the criticism of judicial overreach is bolstered by the conflation of vagueness with the linguistic concept of ambiguity.

Before turning to the cases that I view as exhibiting absurdity in disguise, a further word on the relationship between the absurdity doctrine and purposivism is in order. Professor Richard M. Re previously identified the connection between Holy Trinity Church and three of the cases discussed below ${ }^{120}$ : King $v$. Burwell, ${ }^{121}$ Bond v. United States, ${ }^{122}$ and Yates v. United States. ${ }^{123}$ His article characterizes the Supreme Court's interpretive approach in these cases, which he calls "the New Holy Trinity," as an outright rejection of Justice Scalia's ver-

\footnotetext{
115 See Merrill, supra note 84, at 1091; Molot, supra note 6, at 40-41. Professor Molot has argued that in attempting to distinguish themselves from purposivists, textualists have overemphasized the line between clarity and ambiguity both by being overly willing to conclude that their methods can "eliminate" ambiguity and by making the implications of an ambiguity finding too weighty. $I d$. at 50-51. The manipulation of the line between clarity and ambiguity, he contends, gives textualist judges ample leeway in interpretation, aggravating the problem of the improper exercise of judicial discretion that textualists seek to curtail. See id. at 50. To the extent textualism played a role in elevating the significance of ambiguity findings, its success was instrumental in creating the incentives resulting in absurdity in disguise.

116 JELLUM, supra note 21, at 89.

117 Id. at 87-89.

118 See id.

119 For an in-depth discussion of Hart's problem from a textualist perspective, see SCALIA \& GARNER, supra note 2, at 36-38.

120 See generally Richard M. Re, The New Holy Trinity, 18 GreEn BAG 2d 407, 407-17 (2015), http://www.greenbag.org/v18n4/v18n4_articles_re.pdf [https://perma.cc/HJA6-K4H C].

121 See id. at 413-15.

122 See id. at 409-11.

${ }^{123}$ See id. at 411-13.
} 
sion of strong textualism. ${ }^{124}$ Professor Re contends that in these cases the Supreme Court has "repeatedly and visibly embraced" a more purposive, pragmatic approach. ${ }^{125}$

In contrast, this article views the ongoing interpretive shift as resulting from textualism's success and entrenchment. As illustrated throughout the cases described in Part III below, the Supreme Court opinions identified here and by Professor Re (in addition to two decisions unique to this article) are rife with textualist terminology, principles, and precedent. When statutory purpose is considered, it is frequently (though not exclusively) through the lens of statutory context or the statutory scheme. Separation of powers and the proper role of the judiciary are invoked as paramount concerns. ${ }^{126}$ The realities (and even vagaries) of the legislative process are repeatedly referenced. And, most significantly, ambiguity findings are central to the Court's holdings. This more closely resembles lip service to, as opposed to outright abandonment of textualism: rather than overtly disregard clear text, the text is instead labeled "ambiguous."

A 2006 article by Professor Jonathan T. Molot may further illuminate the distinction. Professor Molot argued that modern textualism is doomed to either irrelevancy or normative unattractiveness because of the lack of meaningful remaining distinctions between its approach and that of purpovisism. ${ }^{127}$ Significantly, he noted that textualists criticize purposivists for "continuing to look to context after they have arrived at a clear textual meaning and of using their ongoing contextual inquiry to adjust or even contradict the clear textual meaning," whereas textualists "purport to use extratextual factors only before arriving at a statute's clear meaning, and never to contradict that clear meaning." ${ }^{128} \mathrm{He}$ argued that these approaches no longer differed importantly in effect and that the differences in methodology were fairly insignificant, primarily as a result of modern textualists' attention to context in the determination of meaning. ${ }^{129}$ Crucially, consider Professor Molot's example of a Supreme Court decision exhibiting the irrelevance of the differing approaches in terms of the outcome. In the same case, a concurring opinion of Justice Thomas noted, "If the text were clear, resort to anything else would be unwarranted. But I agree with the Court that [it] is ambiguous, rather than unambiguous as Justice Stevens con-

124 See Re, supra note 120, at 407 (noting that "purposivism seems to have evolved and, as a result, to have gotten the upper hand").

${ }^{125} I d$. at 408. Earlier works by other scholars predicted similar outcomes, warning that "aggressive" textualists would doom their approach if they insisted on doctrinal rigidity and failed to acknowledge common ground already forged with purposivists. See, e.g., Molot, supra note 6 , at 48 . Professor Jonathan R. Siegel went further, contending that the core tenets of textualism could not be moderated and remain internally consistent; thus, textualism would necessarily, rather than contingently fail as a viable interpretive approach. See Siegel, supra note 5, at 169 .

126 This is not to imply, of course, that only textualists prioritize these concerns.

127 See Molot, supra note 6, at 2.

128 Id. at 4, 37.

129 See id. at 35-36. 
tends." 130 While Justice Stevens noted in his concurrence, "If an unambiguous text describing a plausible policy decision were a sufficient basis for determining the meaning of a statute, we would have to affirm the judgment of the Court of Appeals. ... We can, however, escape ['this unambiguous statutory command'] by using common sense."131

This insight is particularly telling in light of Professor Re's "New Holy Trinity" and absurdity in disguise. Professor Molot may be correct that these approaches do not differ significantly in practice, but the root cause of absurdity in disguise is courts' unwillingness to adopt an overtly purposive approach. Instead, judges purport to adhere to textualist principles and methodology; they employ purposive considerations under the guise of ambiguity rather than openly embrace them as illuminating or modifying otherwise clear text. The obfuscation created by this evasion may entail more significant consequences for methodology and for outcomes. And the incentive to obfuscate explains the utility of absurdity in disguise - a form of reverse-ambiguity via purposivism's close cousin, the absurdity doctrine. ${ }^{132}$

Again, despite the complications outlined above, the determination and resolution of statutory ambiguity is a broadly accepted part of the judicial role, grounded squarely within the process of interpretation (and thus mostly immune from charges of constituting judicial "construction" or lawmaking). The question, then, is how the relatively uncontroversial ambiguity doctrine can be used to conceal the application of other canons like the absurdity doctrine. A number of cases examined in the following section illustrate how this occurs in practice.

The tension between textualism and the absurdity doctrine has manifested itself in decisions at all levels of the federal courts through what I have referred to as "absurdity in disguise." In order to achieve what appears to them to be sensible or correct results, judges have begun to employ findings of ambiguity to open the door to deeper judicial inquiry. This enables judges to portray their reasoning as falling squarely within the interpretive, rather than constructive (note - in the undesirable sense, not construing) realm. And, unlike construction, interpretation is seen by textualists as an entirely appropriate part of the judicial enterprise within the constitutional framework of separation of powers. Thus, judges maintain an aura of objectivity while being permitted to consider the results of various applications of the statutory text.

130 Koons Buick Pontiac GMC, Inc. v. Nigh, 543 U.S. 50, 67 (2004) (Thomas, J., concurring)); see also Molot, supra note 6, at 38 n.160.

131 Molot, supra note 6, at 38 n.160 (quoting Koons Buick Pontiac GMC, Inc., 543 U.S. at 65 (Stevens, J., concurring)).

132 See Re, supra note 120, at 418; see also Manning, supra note 15, at 2400 (noting that the Supreme Court "has traditionally defended the absurdity doctrine as a version of strong intentionalism"). 
The following sections demonstrate the phenomenon in the decisions of several courts confronting contested language in three widely different statutory regimes.

\section{ABSURDITY IN DiSGUISE IN PRACTICE: EXAMPLES FROM RECENT CASES}

Spanning diverse matters at all levels of the federal courts, the cases below share striking commonalities. In all of them, apparently clear text was treated as ambiguous in order to avoid arguably unusual, unreasonable, or unconstitutional results - exactly the analysis that would be employed had the absurdity doctrine been invoked explicitly. The odd or undesirable results of applying the apparently clear text created doubt that the statutes at issue could actually mean what they appear to say. The courts mask this reasoning somewhat by arguing that ambiguity "derived from" or was "created by" the consequences of applying the apparent meanings - the implication being that the ambiguity was preexisting, or at least linguistically present. ${ }^{133}$ But under the traditional, linguistic conception, ambiguity does not exist merely because multiple meanings could possibly be attributed to the text upon further reflection on the consequences. Rather, ambiguity is a textually facial, ex ante phenomenon. Multiple meanings are fairly possible because of the existence of ambiguity; ambiguity does not exist because of the desirability or practicability of one meaning over another. The absurdity doctrine, which imposes ambiguity ex post, in light of the perceived consequences of applying statutory text, is distinguishable from traditional ambiguity for precisely that reason. This is implied in common descriptions of the absurdity doctrine as permitting a judge to "look beyond" clear text or to "treat" clear text as if it were ambiguous.

\section{A. Bond v. United States}

Carol Ann Bond, a microbiologist, discovered that her husband was the father of her best friend's child. ${ }^{134}$ Seeking revenge, she stole an arsenic-based chemical compound from her employer and obtained another chemical used to print photographs and clean laboratory equipment, the latter available on Ama-

\footnotetext{
${ }^{133}$ It is important here to distinguish absurdity in disguise from Supreme Court precedent holding that apparently clear statutory text may actually be found ambiguous when placed in context. The Court has ruled that the "meaning — or ambiguity — of certain words or phrases may only become evident when placed in context" and "with a view to their place in the overall statutory scheme." Food \& Drug Admin. v. Brown \& Williamson Tobacco Corp., 529 U.S. 120, 132-33 (2000). In a sense, ambiguity is also "created" in these instances. However, the primary distinction is that the context and statutory scheme that give meaning to (or illuminate the ambiguity of) a statutory term are textual sources. In contrast, the creation of ambiguity through the application of the absurdity doctrine occurs in light of the consequences of a statute's application. Notably, Justice Scalia joined in the majority opinion in Brown \& Williamson. See id. at 124.

134 Bond v. United States, 572 U.S. 844, 852 (2014).
} 
zon.com. ${ }^{135}$ In high enough doses, both chemicals are potentially lethal. ${ }^{136}$ At least twenty-four times, Bond dabbed small amounts of two chemicals on her former best friend's mailbox, car door, and door knob. ${ }^{137}$ Bond maintained that she did not intend to kill Myrlinda Haynes, the intended victim, but rather intended to cause her to suffer an uncomfortable rash. ${ }^{138}$ Her efforts largely failed; Haynes noticed the presence of the chemicals and avoided them almost entirely. ${ }^{139}$ She did come into contact with a chemical once and received a minor thumb burn, which apparently needed no treatment other than rinsing with water. ${ }^{140}$

Bond was eventually discovered and charged with mail theft after the post office observed her stealing an envelope from Haynes' mail and putting chemicals on Haynes' car. ${ }^{141}$ However, she was also charged with possession and use of a chemical weapon in violation of 18 U.S.C. $\$ 229$ (a), a provision of the Chemical Weapons Implementation Act ("the Act"). ${ }^{142}$ Congress passed the Act to implement the Convention on the Prohibition of the Development, Production, Stockpiling, and Use of Chemical Weapons and on Their Destruction ("the Convention"), a 1997 treaty intended to expand the Geneva Convention's prohibitions of the use of chemical weapons. ${ }^{143}$ The treaty was the result of concerns over the continued use of chemical weapons, including mustard gas and nerve agents, during and outside of wartime up until the 1990s. ${ }^{144}$

In federal district court, Bond argued that the chemical weapons charge should be dismissed because the Act was outside the scope of Congress' power and intruded on traditional state authority in violation of the Tenth Amendment. ${ }^{145}$ After the court denied her motion, she pleaded guilty but reserved her right to appeal. ${ }^{146}$ On appeal, the Third Circuit initially ruled she lacked standing to challenge the Act, but the Supreme Court reversed that decision. ${ }^{147}$ When the case was remanded, Bond argued that the Act was intended to prohibit the use of chemical weapons for "warlike" activities, as evidenced by an exception to the Act that permitted the use of chemical weapons for "peaceful purpos-

\footnotetext{
$135 I d$.

$136 \mathrm{Id}$.

137 Id.

138 Id.

139 Id.

$140 \mathrm{Id}$.

141 Id.

142 Id.

143 Id. at 848-49. The Geneva Protocol's prohibition of chemical weapons extended to state actors during times of war; the Convention broadened this prohibition "to exclude completely the possibility of the use of chemical weapons ..." Id. at 849.

144 Id.

145 Id. at $852-53$.

$146 I d$. at 853.

147 Id.
} 
es." 148 While Bond conceded that her use of chemicals was wrongful, she contended it was not the type of act that the Convention and Act were enacted to prevent. ${ }^{149}$ The Third Circuit disagreed, ruling that Bond's activities certainly could not be considered "peaceful" and were thus outside the exception to the Act. ${ }^{150}$ While the Third Circuit noted that the Act was extremely broad, it nevertheless ruled that it was within Congress' authority because the Convention was valid; thus, a statute enacted to implement it in accordance with the Necessary and Proper Clause is also valid. ${ }^{151}$ The Supreme Court again granted certiorari. ${ }^{152}$

Chief Justice Roberts' opinion for the majority began with a discussion of federalism and enumerated powers, but noted quickly the well-settled principle that these constitutional questions should be avoided if at all possible. ${ }^{153} \mathrm{Be}$ cause Bond had raised the argument that the Act did not even cover her conduct, the Court chose to address the statutory interpretation question first. ${ }^{154}$

The Act provides that no one shall knowingly "develop, produce, otherwise acquire, transfer directly or indirectly, receive, stockpile, retain, own, possess, or use, or threaten to use, any chemical weapon." ${ }^{155}$ In a definitional section, "chemical weapon" is defined as "[a] toxic chemical and its precursors, except where intended for a purpose not prohibited under this chapter as long as the type and quantity is consistent with such a purpose." 156 "Toxic chemical" is defined as:

[A]ny chemical which through its chemical action on life processes can cause death, temporary incapacitation or permanent harm to humans or animals. The term includes all such chemicals, regardless of their origin or of their method of production, and regardless of whether they are produced in facilities, in munitions or elsewhere. ${ }^{157}$

Finally, as noted above, the Act excepts from the prohibition the use of such chemicals for peaceful purposes, including "industrial, agricultural, research, medical, or pharmaceutical activity or other activity ..."158

The Court rejected the Government's argument that the Act clearly encompassed Bond's conduct. Drawing on a number of examples of "background principles of construction," the Court concluded that the statute must be read in light of its context and purpose and consistent with constitutional principles and

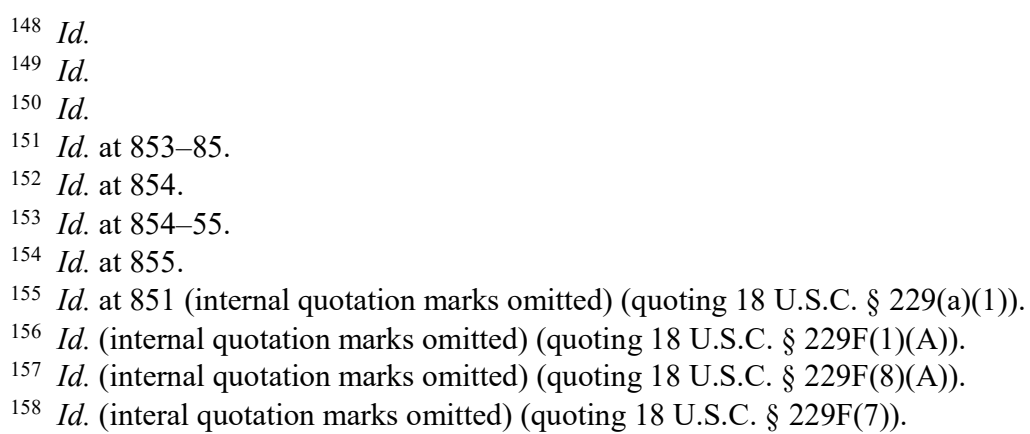


limitations. ${ }^{159}$ Particularly where the balance of power between the federal government and the states is concerned, the Court has been reluctant to construe federal statutes in a way that would intrude on areas of "traditional state responsibility." 160 Citing several cases in which the Court had narrowed the reach of federal statutes on this basis, the Court concluded:

These precedents make clear that it is appropriate to refer to basic principles of federalism embodied in the Constitution to resolve ambiguity in a federal statute. In this case, the ambiguity derives from the improbably broad reach of the key statutory definition given the term- "chemical weapon"-being defined; the deeply serious consequences of adopting such a boundless reading; and the lack of any apparent need to do so in light of the context from which the statute arose - a treaty about chemical warfare and terrorism. We conclude that, in this curious case, we can insist on a clear indication that Congress meant to reach purely local crimes, before interpreting the statute's expansive language in a way that intrudes on the police power of the States. ${ }^{161}$

As other scholars have noted, this reasoning turns that traditional constitutional avoidance canon on its head. ${ }^{162}$ Rather than apply it only after the court finds a statute is ambiguous in order to select among possible interpretations, the canon is employed here in a way that creates ambiguity from apparently clear text. ${ }^{163}$ Notably, the Court addressed Justice Scalia's objection in his concurring opinion that the cases cited by the majority in support of its holding were inapposite because they dealt with statutes that were unclear at the outset: "We agree; we simply think the statute in this case is also subject to construction, for the reasons given." 164 Thus, while concluding that the avoidance principles underlying the previous cases were applicable in Bond, the Court seemingly acknowledged that the source of ambiguity in the instant case differed from the precedent cited.

In concluding the opinion, the Court noted that its disagreement with the dissenting justices "reduces to whether [the Act] is 'utterly clear." "165

We think it is not, given that the definition of 'chemical weapon' in a particular case can reach beyond any normal notion of such a weapon, that the context from which the statute arose demonstrates a much more limited prohibition was intended, and that the most sweeping reading of the statute would fundamentally upset the Constitution's balance between national and local power. This exceptional convergence of factors

\footnotetext{
159 Id. at $857-860$.

$160 \mathrm{Id}$. at 858 .

$161 \mathrm{Id}$. at 859-60.

162 See generally Fish, supra note 97.

163 See id. at 1275.

164 Bond, 872 U.S. at 860 n.2 (emphasis added).

$165 \mathrm{Id}$. at 865.
} 
gives us serious reason to doubt the Government's expansive reading of [the Act], and calls for us to interpret the statute more narrowly. ${ }^{166}$

Perhaps most revealingly, the Court called the case "unusual," and cautioned, "our analysis is appropriately limited." 167 These qualifications are highly suggestive of the conflicts underlying absurdity in disguise. It would be difficult in any case for a judge to ignore entirely the consequences of applying such sweepingly broad text as it is written where the options are effectively either to rewrite federalism or strike the provision as unconstitutional. But perhaps even more important is the difficulty of ignoring these consequences in a case with facts that seem unlike any Congress would have contemplated when drafting the statute. Without the absurdity doctrine as a fail-safe, and with the Court's textualist precedent requiring commitment to statutory text, the only escape from the text was through a finding of ambiguity.

Bond also exploited one of the key characteristics of ambiguity that makes it an effective disguise for the use of the absurdity doctrine. Bond dealt with an extremely broad statute that plainly, but oddly, encompassed conduct that seemed outside the scope of what Congress must have intended to reach. Even though questions of scope are more properly considered problems of vagueness (if anything), the Court classified the statute's problem as one of ambiguity. Although the majority acknowledged in a footnote that it was engaging in "construction" of the statute, its decision to ground its decision in ambiguity perhaps belied its unwillingness to overtly subvert clear meaning. Acknowledging that the statute was vague would have made the Court's use of the absurdity doctrine far more transparent-after all, the infamous Holy Trinity Church ${ }^{168}$ opinion openly narrowed the scope of a broad statutory term. Even Justice Scalia has endorsed the narrow use of the absurdity doctrine as a method of correcting overly broad statutory terms. ${ }^{169}$

Finally, Justice Scalia's concurring opinion is illuminating. He expressed bewilderment over the analysis employed by the majority in reaching its conclusion. He found the statute's meaning to be "plain" and its application to Bond's case "hardly complicated." 170 He blamed the majority's conclusion that the statute was ambiguous on "result-driven antitextualism," noting that it inverted the avoidance canon to hold that potentially unconstitutional effects of applying a statute's plain meaning can render the text ambiguous. ${ }^{171}$ "Imagine what future courts can do with that judge-empowering principle: Whatever has improbably broad, deeply serious, and apparently unnecessary consequences ... is ambiguous!"172 Justice Scalia agreed that the statute was likely unconsti-

166 Id. at 866 .

167 Id. at 865.

168 Holy Trinity Church v. United States, 143 U.S. 457, 460 (1892).

169 See Green v. Bock Laundry Mach. Co., 490 U.S. 504, 527 (1989) (Scalia, J., concurring).

170 Bond, 572 U.S. at 567-68 (Scalia, J., concurring).

171 See id. at 868.

172 Id. at 870. 
tutional due to its breadth, but would not have permitted that result to impact the interpretation. ${ }^{173}$

Although the late Justice accused the majority of "anti-textualism," his frustration may better be explained in light of absurdity in disguise. The majority's opinion did not flatly reject textualism - on the contrary, the majority described its analysis using Justice Scalia's "fair reading" label; took great care to couch its analysis in terms of context, shared understandings, and the background norms of legislating; and invoked ambiguity as a justification for considering broader statutory purposes. Perhaps Justice Scalia's ire came from his perception that his beloved doctrine was overtly invoked, yet turned on its head-largely as a result of its own successes.

\section{B. Asadi v. G.E. Energy (USA), LLC}

The Dodd-Frank Wall Street Reform and Consumer Protection Act of 2010 ("DFA"), a Congressional response to the financial crisis of 2008, provides enhanced protections for whistleblowers who report an employer's violation of various securities or other federal laws. ${ }^{174}$ Although the general trend of the DFA expands on the whistleblower protections authorized by the SarbanesOxley Act of 2002 ("SOX"), ${ }^{175}$ the opposite appears to result under the DFA's anti-retaliation provisions, which protect whistleblowers from adverse action by employers as a result of specified protected activity. ${ }^{176}$ Under SOX, employers are prohibited from retaliating against whistleblowers who either report violations internally to the company (i.e., "inside whistleblowers"), ${ }^{177}$ or who report violations externally to the Securities and Exchange Commission

173 See id. at 872

174 See 15 U.S.C. $\S 78$ u-6(h) (2012); see also Asadi v. G.E. (USA) Energy, L.L.C., 720 F.3d 620, 622-23 (5th Cir. 2013).

175 See Jennifer M. Pacella, Inside or Out? The Dodd-Frank Whistleblower Program's Antiretaliation Protections for Internal Reporting, 86 TEMP. L. REV. 721, 729 (2014) (describing how the DFA's whistleblower provisions "significantly expand upon" those of the Sarbanes-Oxley Act of 2002 by, for example, greatly extending the statute of limitations for suits brought to enforce whistleblower protections).

176 See 15 U.S.C. $\$ 78 \mathrm{u}-6(\mathrm{~h})(1)(\mathrm{A})(2012)$.

177 Under the U.S. Sentencing Guidelines Manual, an organization that is convicted of a crime receives more leniency at sentencing if it had an effective compliance and ethics program in place. Federal Sentencing Guidelines Manual § 8C2.5(f)(1) (U.S. Sentencing Comm'n 2015) (establishing the existence of an effective compliance and ethics program as a mitigating factor at sentencing); id. $\S 8 \mathrm{~B} 2.1$ (defining an effective compliance and ethics program, including the requirement that such program be "reasonably designed, implemented, and enforced so that the program is generally effective in preventing and detecting criminal conduct" but noting that the failure of a program need not mean it is not "generally effective"). The Guidelines provide that an effective compliance and ethics program requires an organization to "take reasonable steps ... to have and publicize a system ... whereby the organization's employees and agents may report or seek guidance regarding potential or actual criminal conduct without fear of retaliation." $I d$. $\S 8 \mathrm{~B} 2.1(\mathrm{~b})(5)$. Thus, the Guidelines incentivize organizations to encourage inside whistleblowing. 
("SEC") ("outside whistleblowers"). ${ }^{178}$ However, the DFA defines a "whistleblower" as "any individual who provides, or 2 or more individuals acting jointly who provide, information relating to a violation of the securities laws to the Commission [the SEC], in a manner established, by rule or regulation, by the [SEC]." 179 The inclusion of "to the Commission" limits the definition to outside whistleblowers, excluding inside whistleblowers who report violations to their employers.

Further, DFA's anti-retaliation protections expressly cover only "whistleblowers":

No employer may discharge, demote, suspend, threaten, harass, directly or indirectly, or in any other manner discriminate against, a whistleblow$e r$ in the terms and conditions of employment because of any lawful act done by the whistleblower-

(i) in providing information to the Commission in accordance with this section;

(ii) in initiating, testifying in, or assisting in any investigation or judicial or administrative action of the Commission based upon or related to such information; or

(iii) in making disclosures that are required or protected under [specified federal laws], and any other law, rule, or regulation subject to the jurisdiction of the Commission. ${ }^{180}$

Thus, on its face, the statute appears to exclude whistleblowers who fail to report securities violations directly to the SEC from the ambit of the DFA's antiretaliation protections. Nevertheless, the SEC issued a rule pursuant to its regulatory authority under the statute providing that the "whistleblowers" protected under the anti-retaliation provisions include both inside and outside whistleblowers. ${ }^{181}$ The SEC relied on the third prong of the DFA's anti-retaliation protections, which protect disclosures "required or protected under" numerous federal laws, including SOX. ${ }^{182}$ Because SOX protects both internal and external whistleblowers, the SEC reasoned that internal whistleblowers were covered under the third prong of DFA's anti-retaliation provisions, despite not being included in the DFA's definition of whistleblower. ${ }^{183}$

Two federal circuit courts and numerous district courts have addressed this issue. Most of the district courts have ruled that the DFA does protect inside

\footnotetext{
178 See 18 U.S.C. $§ 1514$ A(a)(1)(A)-(C) (2012); see also Pacella, supra note 175, at 732 (noting that "§ 806 of SOX clearly protects both internal and external whistleblowers").

17915 U.S.C. $\S 78 \mathrm{u}-6(\mathrm{a})(6)$ (2012) (emphasis added).

180 Id. $\S 78 \mathrm{u}-6(\mathrm{~h})(1)(\mathrm{A})$ (emphasis added).

18117 C.F.R. § 240.21F-2(b) (2019), invalidated by Asadi v. G.E. Energy, L.L.C., 720 F.3d 620 (5th Cir. 2013) ("For purposes of the anti-retaliation protections afforded by [15 U.S.C. $\S 78 \mathrm{u}-6(\mathrm{~h})(1)]$, you are a whistleblower if . . . [y]ou provide . . . information in a manner described in [15 U.S.C. $\S 78 \mathrm{u}-6(\mathrm{~h})(1)(\mathrm{A})] . ”)$.

18215 U.S.C. $\S 78 \mathrm{u}-6(\mathrm{~h})(1)(\mathrm{A})(\mathrm{iii}) ; 17$ C.F.R. $\S 240.21 \mathrm{~F}-2$ (b).

183 See Pacella, supra note 175, at 730-33 for a detailed summary of the SEC's process in enacting the rule.
} 
whistleblowers. ${ }^{184}$ Notably, the Fifth and Second Circuits have reached opposite conclusions on the issue. Below, I contrast the opinions of the Fifth and Second Circuits, which offer a remarkable illustration of absurdity in disguise and textualism's role in its existence.

The Fifth Circuit's decision, Asadi v. G.E. Energy (USA), LLC, ${ }^{185}$ offers a classic textualist analysis of the statute. Early in the court's analysis, it emphasized the preeminence of statutory text: "When faced with questions of statutory construction, 'we must first determine whether the statutory text is plain and unambiguous' and, '[i]f it is, we must apply the statute according to its terms." "186 "If the statutory text is unambiguous, our inquiry begins and ends with the text." 187 Turning to the definition section, the court concluded that the DFA's definition of "whistleblower," at least "standing alone," clearly applied only to whistleblowers who report violations to the SEC. ${ }^{188}$

The court rejected the holdings of several district courts who found either that the statutory scheme was ambiguous or conflicting ${ }^{189}$ because of the ten-

184 For a more complete list of citations to district court decisions on the issue, see Berman v. Neo@Ogilvy LLC, 801 F.3d 145, 153 (2d Cir. 2015).

185 Asadi v. G.E. Energy, LLC, 720 F.3d 620 (5th Cir. 2013).

$186 I d$. at 622 (alteration in original) (quoting Carcieri v. Salazar, 555 U.S. 379, 387 (2009)).

187 Id. (citing BedRoc Ltd. v. United States, 541 U.S. 176, 183 (2004)).

188 See id. at 623.

189 See id. at 624-25, 624 n.6. In an interesting (though unreported) decision, a district court found that the DFA's whistleblower provision and anti-retaliation provisions contradicted one another, but noted that the plaintiff's argument that Congress intended the definition to include inside whistleblowers would read the phrase "to the Commission" out of the definition entirely, rendering the phrase surplusage. See Egan v. TradingScreen, Inc., No. 10 Civ. 8202(LBS), 2011 WL 1672066, at*4-5 (S.D.N.Y. May 4, 2011). In light of this, the court resolved the conflict by treating the third prong of the anti-retaliation provision as a "narrow exception" to the DFA's whistleblower definition, thus protecting only those inside whistleblowers whose disclosures fall under the third prong (finding that the third prong creates a broader definition of "whistleblowers" than is applicable under the rest of the statutory scheme). See $i d$. at *5. Notably, the court began this analysis by noting its duty to first "determine whether the language at issue has a plain and unambiguous meaning with regard to the particular dispute in the case." Id. at *4 (internal quotation marks omitted) (quoting Barnhart v. Sigmon Coal Co., 534 U.S. 438, 450 (2002)). For similar analyses citing Egan, see Genberg v. Porter, 935 F. Supp. 2d 1094, 1106 (D. Colo. 2013) (noting that the "plain language" of the DFA encompasses only outside whistleblowers, but following Egan's "narrow exception" holding because the DFA's whistleblower definition "is in direct conflict" with its anti-retaliation provisions); Nollner v. S. Baptist Convention, Inc., 852 F. Supp. 2d 986, 994 (M.D. Tenn. 2012). Other district courts adopting the "narrow exception" characterization more explicitly viewed the issue as one of ambiguity: "I do not believe it is unambiguously clear that the Dodd-Frank Act's retaliation provision only applies to [outside whistleblowers]." See Kramer v. Trans-Lux Corp., No. 3:11CV1424, 2012 WL 4444820, at *4 (D. Conn. Sept. 25, 2012); see also Murray v. UBS Sec., LLC, No: 12 Civ. 5914(JMF), 2013 WL 2190084, at *4 (S.D.N.Y. May 21, 2013) (deferring to the SEC's interpretation of the DFA after finding statutory ambiguity "aris[ing] from the tension between" the definition and the anti-retaliation provisions). The Murray court found that both the "narrow exception" interpretation and an interpretation limiting anti-retaliation protections solely to outside whistleblowers were both "competing, plausible interpretations"; thus, the text "is ambiguous in conveying Congress's intent." Id. at *5 (internal quotation marks omitted) (quoting 
sion between the DFA's definition section and its anti-retaliation provisions. ${ }^{190}$ The court distinguished between the definition's classification of protected persons from the anti-retaliation provision's classification of protected activities. ${ }^{191}$ A conflict would only arise, the court reasoned, if both sections of the DFA were read as definition sections. ${ }^{192}$ The court bolstered this conclusion by noting that interpreting the DFA to cover inside whistleblowers would render the clause "to the [SEC]" in its definition section superfluous. ${ }^{193}$ Moreover, bringing inside whistleblowers under the purview of the DFA through the third prong of the anti-retaliation provision would arguably render SOX's antiretaliation protections largely superfluous, as well, at least in the sense that every SOX anti-retaliation claim could be brought instead under the DFA. ${ }^{194}$

Throughout the Fifth Circuit's decision, it frequently referred to plain meaning and unambiguous text in support of its decision that some have argued flies in the face of the DFA's clear intent to enlarge the whistleblower protections under SOX. ${ }^{195}$ The Second Circuit, which examined the issue in Berman v.Neo@Ogilvy LLC, ${ }^{196}$ took a vastly different approach. The court's introductory sentences immediately highlighted the apparent "tension" in the DFA's whistleblower protection provisions and concluded that "the pertinent provisions of Dodd-Frank create a sufficient ambiguity to warrant our deference to the SEC's interpretive rule ..." 197 And after describing the background of the case and the statutory scheme at issue, the court again used this description:

$[\mathrm{T}]$ he more precise issue in the pending appeal is whether the arguable tension between the definitional section .... and [the third prong of the anti-retaliation provision] creates sufficient ambiguity as to the coverage of [the third prong] to oblige us to give Chevron deference to the SEC's rule. ${ }^{198}$

Cohen v. JP Morgan Chase \& Co., 498 F.3d 111, 120 (2d Cir. 2007)). The court found that the existence of ambiguity warranted Chevron deference and also invoked the rule against surplusage in support of the "narrow exception" reading. See id. For a district court decision rejecting these decisions, see Verfuerth v. Orion Energy Sys., Inc., 65 F. Supp. 3d 640 (E.D. Wisc. 2014) ("In short, the belief that there is some kind of conflict in the statute is based on a flawed understanding of the concept of statutory ambiguity.").

190 See Asadi v. G.E. Energy, L.L.C., 720 F.3d 620, 625-26 (5th Cir. 2013).

191 Id. at 625 ("The three categories listed in [15 U.S.C.] $\S 78 \mathrm{u}-6(\mathrm{~h})(1)(\mathrm{A})$ represent the protected activity in a whistleblower-protection claim. They do not, however, define which individuals qualify as whistleblowers.").

192 Id. at 626.

193 Id. at 628.

194 See id.

195 See, e.g., Pacella, supra note 175, at 743-48.

196 Berman v. Neo@Ogilvy LLC, 801 F.3d 145 (2d Cir. 2015).

197 Id. at 146 (emphasis added). Perhaps even more tellingly, the court explicitly compared the situation to the Supreme Court's decision on the Affordable Care Act in King v. Burwell, 135 S. Ct. 2480, 2506 (2015), discussed in the following section of this article as another example of absurdity in disguise. See id. at 150, 155; infra Section III.C.

198 Id. at 148 (citing Chevron, U.S.A., Inc. v. Nat. Res. Def. Council, Inc., 467 U.S. 837 (1984)). 
The Second Circuit invoked "tension" (although not direct conflict) between two provisions at issue, along with one provision's last-minute addition during the legislative process - this latter argument, ironically, typically used to justify the textualist approach to statutory interpretation. Turning to its analysis, the court determined that although there was "no absolute conflict" between the two provisions, it nevertheless agreed with the findings of many district courts that there was tension between the provisions. ${ }^{199}$ The court examined the legislative history for a resolution and found nothing directly on point, but did note that the anti-retaliation third prong had been inserted close to the end of the drafting process. ${ }^{200}$ While the court acknowledged that statutorily defined terms generally are to be read literally and applied throughout the applicable portions of the statute, it found these general rules inapposite in light of prong three's late insertion in the statute. ${ }^{201}$ The court cited the complexities of the legislative process in support of this finding. ${ }^{202}$ The court noted that the realities of legislative drafting also suggested that the last-minute insertion of the third antiretaliation prong may have been done hastily and without the intent that it be limited by the narrow definition provision. ${ }^{203}$ Essentially, the tension at least raised the question of congressional intent; because the court could not resolve the question based on the text or using legislative history, it found the statute ambiguous. ${ }^{204}$ "[T] he tension [in the DFA] renders [it] sufficiently ambiguous to oblige us to give Chevron deference .... [W] need not resolve the ambiguity ourselves, but will defer to the reasonable interpretive rule adopted by the appropriate agency." 205

Stunningly, while couching its reasoning in terms of an ambiguity analysis, the court initially compared the case to Holy Trinity Church, ${ }^{206}$ the classic paragon of the absurdity doctrine. Most significantly, the court appeared to back away from the comparison, finding that another case was "[c]loser" to the

199 See id. at $150-51$.

200 See id. at $152-55$.

201 See id. at 154.

202 Id. The court also used its legislative process arguments to reject arguments from both parties invoking the rule against surplusage, which was a key component of the Asadi court's decision and many district court rulings on the issue. See id. Even textualists concede that the rule should be one of the earliest to jettison precisely because of the realities of legislative drafting. SCALIA \& GARNER, supra note 2, at 176, 179. Overall, the court's invocation of these arguments demonstrates the significant influence of textualism on modern statutory interpretation - even courts ultimately guided by statutory purpose and congressional intent take pains to justify their decisions using textualist doctrine.

203 Berman, 801 F.3d at 154-55.

204 See id. at 155.

${ }^{205}$ Id. (emphasis added). Notably, the Supreme Court resolved the DFA circuit split in 2018 in Dig. Realty Tr., Inc. v. Somers, 138 S. Ct. 767, 776 (2018). Upon concluding that the statutory definition unambiguously includes only those whistleblowers who report to the SEC, the Court declined to apply Chevron deference to the SEC's interpretation of the rule. Id. at 782.

206 Berman, 801 F.3d at 150. 
case at bar-King v. Burwell, ${ }^{207}$ the Supreme Court's decision on the Affordable Care Act ("ACA"). In Burwell, the Court considered a definitional provision of the ACA that appeared to limit the availability of income tax subsidies to those insured through state-established, but not federally-established health exchanges. ${ }^{208}$ However, that limitation would have undermined the statutory scheme and appeared vastly at odds with what the ACA was purportedly designed to do. ${ }^{209}$ As discussed in further detail in Section III.D, Burwell is another case in which a court used the anomalous result of applying apparently plain text to conclude that statutory text was ambiguous.

This case exhibits a fairly low, Holy Trinity Church-type conception of absurdity, where the apparent meaning is not literally illogical or incomprehensible, but nevertheless odd and inconsistent with what is known about the purpose of the statute. But even as the Second Circuit recognized the parallels between its reasoning and Holy Trinity Church, ${ }^{210}$ it ultimately characterized its decision as grounded in statutory ambiguity- "[c]loser" to King v. Burwell. ${ }^{211}$ The concept of ambiguity in disguise reveals that both of the Second Circuit's comparisons were accurate because, in substance, King v. Burwell ${ }^{12}$ operated precisely the same way as Holy Trinity Church. ${ }^{213}$ The decisions differ primarily in characterization, not operation: the hallmarks of absurdity in disguise. ${ }^{214}$

\section{National Federation of Independent Business v. Sebelius}

The Supreme Court of the United States confronted the first major challenge to the ACA in 2012 in National Federation of Independent Business $v$.

207 Id.

208 King v. Burwell, 135 S. Ct. 2480, 2490-91 (2015).

209 See id. at 2493. The Berman court's discussion of the Supreme Court's King v. Burwell decision is some of the strongest evidence of absurdity in disguise in all the opinions examined herein - in fact, absurdity is nearly unmasked.

210 Berman, 801 F.3d at 150.

211 Id.

212 See generally Burwell, 135 S. Ct. at 2480.

213 See generally Holy Trinity v. United States, 143 U.S. 457 (1892).

214 Professor Richard M. Re previously identified the connection between Holy Trinity Church, King v. Burwell, Bond v. United States, and Yates v. United States. See Re, supra note 120, at 408-17. However, like other scholars, he views "the New Holy Trinity" as an outright rejection of Justice Scalia's version of strong textualism. See id. at 407-08 (noting that "purposivism seems to have evolved and, as a result, to have gotten the upper hand"). Further, Professor Re contends that the Supreme Court has "repeatedly and visibly embraced" a more purposive, pragmatic approach. Id. at 408. Earlier works by other scholars predicted similar outcomes, warning that "aggressive" textualists would doom their approach if they insisted on doctrinal rigidity and failed to acknowledge common ground already forged with purposivists. See, e.g., Molot, supra note 6, at 48. Professor Jonathan R. Siegel went further, contending that the core tenets of textualism could not be moderated and remain internally consistent; thus, textualism would necessarily, rather than contingently fail as a viable interpretive approach. See Siegel, supra note 5, at 169-73, 176. 
Sebelius. ${ }^{215}$ Congress enacted the Patient Protection and ACA in 2010 with the goals of reducing health care costs and improving health insurance coverage rates in the United States. ${ }^{216}$ One of the ACA's most significant provisions is an "individual mandate," which requires most Americans to purchase health insurance coverage; if an individual chooses not to do so, he or she must pay what the ACA calls a "penalty" to the Internal Revenue Service. ${ }^{217}$ In Sebelius, one of the challengers' key arguments was that this central provision was an unconstitutional exercise of Congress' power because it extended beyond the reach of the Tax and Spend Clause under Article I, Section 8 of the Constitution. ${ }^{218}$

The Government argued that the mandate should be interpreted not as requiring individuals to purchase insurance, but as a tax on those who choose not to purchase it, despite the ACA's mandatory language and characterization of the payment for noninsurance as a "penalty." ${ }^{19}$ Addressing this contention, the majority of the Court noted that the "most straightforward reading of the mandate is that it commands individuals to purchase insurance." ${ }^{220}$ If that were the case, the mandate could not fall within Congress' power to tax and spend. ${ }^{221}$ And, as the Court had already ruled that the individual mandate was not within Congress' commerce power, the mandate would be struck down if the Court found it beyond the Tax and Spend Clause. ${ }^{222}$

Although the Court frequently used language evoking ambiguity, it is clear that the high stakes of the potential result-striking down the individual mandate - was the lodestone of its opinion. The most persuasive support for this proposition can be found in the Court's own words: "The text of a statute can sometimes have more than one possible meaning .... And it is well established that if a statute has two possible meanings, one of which violates the Constitution, courts should adopt the meaning that does not do so." ${ }^{223}$ As another example: "The question is not whether that is the most natural interpretation of the mandate, but only whether it is a 'fairly possible' one. As we have ex-

215 See Nat'l Fed'n of Indep. Bus. v. Sebelius, 567 U.S. 519, 530-31 (2012).

216 Id. at 538.

217 Id. at 539.

218 See id. at 540. Additionally, the challengers contended that the ACA was impermissible under the Commerce Clause, the other constitutional provision invoked by the Government in support of Congress' authority to enact the law. See id. Finally, the challengers also disputed the constitutionality of the ACA's expansion of Medicaid. See id. at 541 .

${ }^{219} I d$. at 562, 564. It is worth noting here that the Court also conceded that the Government's proposed reading of the statute was entirely at odds with the reading it advocated in support of its primary argument that the ACA was authorized by the Commerce Clause. See $i d$. at 561. Moreover, the Court determined that the Anti-Injunction Act did not bar it from hearing the case on the ground that the ACA described the individual mandate as imposing a "penalty," not a tax. See id. at 564.

220 Id. at 562.

221 See id.

222 See id. at 561.

$223 \mathrm{Id}$. at 562. 
plained, 'every reasonable construction must be resorted to, in order to save a statute from unconstitutionality." "224 And, most explicitly:

It is only because the Commerce Clause does not authorize such a command that it is necessary to reach the taxing power question. And it is only because we have a duty to construe a statute to save it, if fairly possible, that $\S 5000 \mathrm{~A}$ can be interpreted as a tax. ${ }^{225}$

These quotes evidence more than just a low threshold for an initial finding of ambiguity - on the contrary, the ambiguity finding was the result of the consequences of its absence. Significantly, the Court called the interpretation of the mandate as a penalty both the "most straightforward" and "the most natural" reading. ${ }^{226}$ These descriptions seem far more akin to the characteristics of the ordinary meaning favored by modern judges than to hyperliteralism of earlier forms of "plain meaning" textualism. It is certainly uncharacteristic of "classic" ambiguity given that the Court explicitly found one interpretation clearly more plausible than another. In virtually every instance, a statutory provision could be given more than one possible meaning - after all, were this not the case, the absurdity doctrine's solution of treating clear texts as ambiguous would never resolve any of the problems it was designed to confront. Even minimal standards of ambiguity typically require multiple plausible meanings at the very least. ${ }^{227}$ Also tellingly, the Court's description of the interpretation ultimately adopted as "fairly possible" is prototypical of the interpretations adopted in absurdity cases: even though a statute seems clear, a less intuitive, less obvious meaning is adopted instead to avoid undesirable consequences. Thus, Sebelius also exemplifies the feasibility of employing ambiguity due to the concept's malleability.

\section{King v. Burwell and Halbig v. Burwell}

The second major challenge to the ACA arose in King v. Burwell, ${ }^{228}$ a Fourth Circuit decision that was eventually reviewed by the Supreme Court. At the same time the Fourth Circuit ruled in King, the D.C. Circuit ruled in a case brought on the same grounds in Halbig v. Burwell. ${ }^{229}$ The majority in Halbig offers an interesting contrast to the Fourth Circuit's decision, so it is also examined below after a brief overview of the issues under review.

In these cases, the plaintiffs challenged an IRS rule passed under the authority of the ACA that authorized tax credits for individuals who purchased

${ }^{224}$ Id. at 563 (quoting Hooper v. California, 155 U.S. 648, 657 (1895)).

$225 \mathrm{Id}$. at 574.

${ }^{226}$ Id. at 562-63. The Court's belief that this interpretation was the "most natural" can be inferred from the Court's statement that "[ $[\mathrm{t}]$ he question is not whether that is the most natural interpretation of the mandate, but only whether it is a 'fairly possible' one." See id. at 563 (quoting Crowell v. Benson, 285 U.S. 22, 62 (1932)).

227 See, e.g., Jellum, supra note 21, at 87-88.

228 King v. Burwell, 759 F.3d 358, 365 (4th Cir. 2014), aff'd, 135 S. Ct. 2480 (2015).

229 Halbig v. Burwell, 758 F.3d 390, 412 (D.C. Cir. 2014). 
insurance through either state-run or federally-run health exchanges. ${ }^{230}$ The establishment of state exchanges is governed by ACA $\S 1311$, which requires each state to establish a health exchange. ${ }^{231}$ A separate provision, $\S 1321$, provides that if a state elects not to establish its own exchange, the Secretary of the Department of Health and Human Services ("HHS") "shall ... establish and operate such Exchange within the State ...."232 In the definition section of the ACA, "Exchange" is defined as "an American Health Benefit Exchange" established under $\S 1311.233$

In tandem with the individual mandate (the subject of the previous major challenge to the statute), the ACA provided for tax credits to subsidize the purchase of health insurance as another means of making coverage affordable. ${ }^{234}$ This "premium assistance credit" is calculated based on a taxpayer's monthly premiums for a health plan "enrolled in through an Exchange established by the State under [§ 1311 of the ACA] . ...235 Finally, the term "State" is defined in the statute consistent with normal usage (i.e., not including the federal government). ${ }^{236}$ The plaintiffs in King and Halbig argued that the text of the ACA plainly limits these premium tax credits to individuals purchasing insurance through state exchanges because a federally-established exchange cannot be "an Exchange established by the State ..."237 Thus, the IRS rule purporting to provide them to those insured through federal exchanges is contrary to the ACA. $^{238}$

\section{King v. Burwell in the Fourth Circuit}

The Fourth Circuit rejected the plaintiffs' contention that the plain language of the text precluded the IRS rule. Instead, the court found that the statutory text was "ambiguous and subject to multiple interpretations" 239 while acknowledging at the same time that "there is a certain sense to the plaintiffs' position" that "the language says what it says[.]" 240 The majority went on to remark that the plaintiffs' arguments had "common-sense appeal" and that "a literal reading of the statute undoubtedly accords more closely with their position." ${ }^{241}$ Furthermore, the court acknowledged that Congress could have used broader language - as it did in other places throughout the statute - had it in-

230 See Halbig, 758 F.3d at 395; King, 759 F.3d at 364.

231 See Halbig, 758 F.3d at 394; King, 759 F.3d at 364.

232 See 42 U.S.C. § 18041(c)(1) (2012).

${ }^{233}$ Id. $\S 18031(\mathrm{~b})(1)$.

234 See 26 U.S.C. § 36B (2012).

235 Id. (emphasis added).

23642 U.S.C. § 18024(d) (2012).

237 Halbig, 758 F.3d at 398; King, 759 F.3d at 368.

238 Halbig, 758 F.3d at 398; King, 759 F.3d at 368.

239 King, 759 F.3d at 363.

$240 I d$. at 368.

${ }^{241} I d$. at 369. 
tended to provide the tax credits to persons insured in both state and federal exchanges. ${ }^{242}$

Still, at first blush, the court's ambiguity finding appears to be textuallybased, rather than policy-based. As noted, $\S 1311$ purports to require each state to establish a health exchange and provides that "[a]n Exchange shall be a governmental agency or nonprofit entity that is established by a State." ${ }^{243}$ Moreover, the ACA's definition section defines the statutory term "Exchange" as "an American Health Benefit Exchange" established under [§] 1311. ${ }^{244}$ However, $\S 1321$ of the ACA provides that the states may elect whether to establish an exchange under $\S 1311$; in the event that a state does not, $\S 1321$ (c) requires that the federal government do so. ${ }^{245}$ The court emphasized the language of $\S 1321$ (c), which provides that the HHS Secretary " "shall ... establish and operate such Exchange within the State ..." "246 The court concluded that the reference to "such Exchange" could operate to make federally-established exchanges the equivalent of state exchanges under $\S 1311$ - thus, by definition, exchanges established by a state. ${ }^{247}$

The majority noted repeatedly that it found this construction more persuasive than the plaintiffs'. ${ }^{248}$ Notably, in a concurring opinion, Judge Davis agreed with this conclusion to such an extent that he found the statute unambiguous. ${ }^{249}$ Even while characterizing the plaintiffs' reading as the "straightforward" one, he concluded that their reading "strips away any and all possible explanations for why Congress would have intended to exclude consumers who purchase health insurance coverage on federally-run Exchanges from qualifying for premium tax credits." ${ }^{250}$ Congress could not have intended "a reading that has no legislative history to support it and runs contrary to the Act's text, structure, and goals" and which would "render[] the entire Congressional scheme nonsensical." 251

Although the majority declined to adopt the concurring judge's conclusion that the statute was clear, it was by no means blind to the policy consequences noted in the concurrence. On the contrary, the majority found it was "clear that widely available tax credits are essential to fulfilling the Act's primary goals and that Congress was aware of their importance when drafting the bill." ${ }^{252} \mathrm{In}$ deed, "the economic framework supporting the Act would crumble if the cred-

$242 I d$. at 368 .

24342 U.S.C. $\S 18031(\mathrm{~d})(1)(2012)$.

${ }^{244}$ Id. $\S 18031(\mathrm{~b})(1)$.

245 See id. $§ 18041$.

${ }^{246}$ King, 759 F.3d at 369 (quoting 42 U.S.C. § 1321(c)).

247 Id.

248 See id. at 369-71.

249 See id. at 378 (Davis, J., concurring).

250 Id.

251 Id.

252 Id. at 374. 
its were unavailable on federal Exchanges" and "without an exception to the individual mandate, millions more Americans unable to purchase insurance without the credits would be forced to pay a penalty that Congress never envisioned imposing on them." 253 "Tellingly, the plaintiffs do not dispute that the premium tax credits are an essential component of the Act's viability." 254

Significantly, however, the majority addressed the implications of the competing constructions only after finding the statute ambiguous and as part of its analysis of whether to afford Chevron deference to the IRS interpretation of the statute. ${ }^{255}$ The quotes in the preceding paragraph supported the court's conclusion that the IRS rule was a permissible construction of the statute and thus entitled to Chevron deference. ${ }^{256}$ As evidenced by the concurrence, it would certainly have been possible to use the quoted propositions to bolster the conclusion that the statute unambiguously permitted the availability of credits for federal exchange insureds - though that would require a much more transparently purposive interpretive approach. At the same time, in a literal sense, a federally-established exchange cannot be an exchange "established by the State." The majority was unwilling to disregard the literal, "common sense" reading of the text, but neither could it ignore the implications of rigid adherence to it. Invoking Chevron - which requires an analysis of whether an agency's interpretation is permissible, not whether it is consistent with the most natural reading (i.e., ordinary meaning) - permitted the court to consider policy implications indirectly, through the discussion of the competing concerns weighed by the agency. The court's use of ambiguity to open the door to Chevron is even more noteworthy given the court admitted that it found the Government's construction more persuasive than the plaintiffs', despite noting the "literal" import of the text and "the common-sense appeal of the plaintiffs' argument ..." ${ }^{257}$ And, as noted, the concurring opinion offered a path to the same result without a finding of ambiguity. The majority's ambivalence evinces a reluctance to adopt overtly purposive reasoning and a discomfort with the results of adopting a "purely" textualist approach. ${ }^{258}$ Finding the text ambiguous per-

$253 I d$. at 375.

254 Id.

255 See id. at 373-75.

256 See id.

257 Id. at 369.

${ }^{258}$ I do not contend here that textualism would necessarily or indisputably require a finding that the tax credits were unavailable to consumers in federal exchanges. As emphasized throughout this article and in the literature on modern textualism generally, textualism does not seek "hyper-literal" interpretations; instead, the meanings of statutory terms are to be considered contextually. Of course, the scope of that context and the dividing line between literal and hyper-literal interpretations are debated even among judges and scholars selfidentifying as textualist. However, Justice Scalia, textualism's most prominent proponent, later took the position that textualism clearly mandated the plaintiffs' construction. See King v. Burwell, 135 S. Ct. 2480, 2496-97 (2015) (Scalia, J., dissenting). Although admittedly speculative, the claim that most judges and scholars familiar with his work would have expected this outcome does not seem overly controversial. 
mitted the incorporation of statutory purpose and policy into the majority's decision in a less controversial way than the concurrence's overtly resultsoriented approach..$^{259}$

\section{Halbig v. Burwell in the D.C. Circuit}

In the same month the Fourth Circuit ruled in King v. Burwell, ${ }^{260}$ the D.C. Circuit ruled in Halbig v. Burwell, ${ }^{261}$ a case raising the same challenge to the availability of tax credits to insurance purchasers in federal exchanges under the IRS's interpretation of the ACA. The D.C. Circuit's majority opinion reached a result different from both the majority and concurring opinions of the Fourth Circuit in King: the court ruled that the ACA unambiguously permitted tax credits only for purchasers of insurance in state exchanges because federal exchanges are not exchanges established by a state. ${ }^{262}$

The D.C. Circuit agreed that $\S 1321$ 's requirement that HHS establish "such Exchange" in the event that a state elects not to do so created an equivalence between state and federal exchanges "in terms of what they are and the statutory authority under which they are established." ${ }^{263}$ However, the court found that this equivalence did not extend to the treatment of state and federal exchanges for the purpose of the tax credits because the "subsidies also turn on a third attribute of Exchanges: who established them." ${ }^{664}$ The "such Exchange" language in $\S 1321$, while referencing $\S 1311$, did not make federallyestablished exchanges "established by the State" simply in virtue of being treated as established under the same statutory provision. ${ }^{265}$ The court emphasized that Congress easily could have ensured that federal exchanges were treated exactly like state exchanges by explicitly requiring it - as it did, in fact, with respect to exchanges created by U.S. territories, in which case the territories are to "be treated as a State." 266

The majority also rejected a dissenting judge's argument that $\S 1311(\mathrm{~d})(1)$ provided this equivalency, concluding instead that it is not a definition section. ${ }^{267}$ The ACA's definition section simply defines exchanges as those established under $\S 1311 .{ }^{268}$ The court concluded it would be incongruous at best for

259 And, as noted, the primacy of statutory text is well-established in Supreme Court precedent on interpretation and textualism's influence on this precedent is widely acknowledged. Thus, we should expect that Fourth Circuit judges concerned with properly adhering to precedent would be wary of undermining statutory text and, thus, inclined to couch their reasoning in textualist-leaning terms.

260 King, 759 F.3d at 359.

261 Halbig v. Burwell, 758 F.3d 390 (D.C. Cir. 2014).

${ }^{262}$ Id. at 393-94.

263 Id. at 399-400.

$264 \mathrm{Id}$. at 400.

265 Id. at 398-99.

266 See id. at 400

267 See id. at 400-01.

268 See id. at 399 (citing 42 U.S.C. § 300gg-91(d)(21)). 
Congress to choose $\S 1311$, which authorizes state exchanges, as the place to alter the ACA's general definition of exchange and essentially create a legal fiction with regard to the treatment of federal exchanges. ${ }^{269}$

The court next considered and rejected the Government's argument that the plaintiffs' construction of the text rendered various other provisions of the ACA absurd. Emphasizing the high threshold for absurdity and the concerns that broad versions of the absurdity doctrine pose for "the rule-of-law objectives implicit in the Constitution's strict separation of lawmaking from judging," 270 the court found that no result of applying the plain meaning of the text was irreconcilable with either the apparent or conceivable purpose of the statutory scheme. ${ }^{271}$ Moreover, the court emphasized the vagaries of the legislative bargaining process, noting that the Supreme Court has cautioned that "no legislation pursues its purposes at all costs." 272

Significantly, the majority concluded by admitting that it reached its decision "frankly, with reluctance" given the "major consequences" and "high ... stakes" involved. ${ }^{273}$ Nevertheless, "Congress is supreme in matters of policy, and the consequence of that supremacy is that our duty when interpreting a statute is to ascertain the meaning of the words of the statue duly enacted through the formal legislative process." 274

\section{The Supreme Court's Decision in King v. Burwell}

In light of the conflicting opinions of the Fourth and D.C. Circuits in King and Halbig, the Supreme Court granted certiorari in King v. Burwell ${ }^{275}$ to consider the validity of the IRS rule making tax credits available to insureds in both state and federal exchanges. After briefly reviewing the history and key mechanisms of the ACA, Chief Justice Roberts, writing for the majority, addressed whether Chevron deference should be afforded to the IRS. ${ }^{276}$ Breaking

269 See id. at $400-01$.

270 See id. at 402 (summarizing John F. Manning, The Absurdity Doctrine, 116 HARV. L. REV. 2387, 2434-35 (2003)).

271 See id. at 402-06.

272 Id. at 411 (citations omitted).

273 Id. at 412.

${ }^{274} I d$. A concurring opinion filed in the case was even more matter of fact in its textualist underpinnings, arguing that adopting the Government's construction "would be to engage in distortion, not interpretation." See id. (Randolph, J., concurring). On the contrary, a vigorous dissent filed by Judge Edwards would have found the statute ambiguous, largely on the ground that the plaintiffs' construction would "thwart a central element of the ACA." See id. at 413 (Edwards, J., dissenting). "It is inconceivable that Congress intended to give States the power to cause the ACA to "crumble." "Id. While the dissent in Halbig is a paradigmatic example of absurdity in disguise, the opinion is not discussed in detail here to avoid redundancy in light of its similarity to the Supreme Court's majority opinion in its review of King v. Burwell. See infra Part III.D.3.

275 King v. Burwell, 135 S. Ct. 2480 (2015).

276 See id. at 2488-89. 
from the approaches of the lower courts, the Court summarily ruled that even if the ACA was ambiguous, Chevron was inapposite. ${ }^{277}$ The significance of the issue from both a political and economic standpoint made this one of the rare and "extraordinary" cases in which it is inconceivable that Congress could have intended to delegate the decision to an agency. ${ }^{278}$ Rather, the majority concluded that even if the statutory language was ambiguous, the resolution of its meaning must be determined by the Court. ${ }^{279}$

The Court next turned to the text of the relevant statutory provisions, emphasizing the importance of context and the broad statutory scheme in the determination of the meaning of statutory text. ${ }^{280}$ Relying in part on the "such Exchange" language of $\S 1321$, the Court found that the phrase "an Exchange established by the state under [ $\S 1311]$ " was ambiguous. ${ }^{281}$ Although the Court acknowledged that the phrase "established by the State" would be entirely superfluous had Congress intended that the credits be available for both state and federal exchanges, it brushed this concern aside on the ground that the canon against surplusage is "not absolute." 282 More tellingly, the Court noted the "such Exchange" language only after an extensive discussion of healthcare reform in the United States going back to the 1990s. ${ }^{283}$ Moreover, the Court frankly acknowledged that the Government's interpretation was not the "most natural reading." ${ }^{284}$ Nevertheless, that reading was adopted because it was most consistent with the Court's view of the purpose of the legislation - surely, the Court noted, Congress must have intended the tax credits to make the ACA work; it could not have intended to embed a limitation that would ultimately destroy legislative scheme. ${ }^{285}$

In King, Sebelius, and Bond, the Supreme Court invoked the constitutional avoidance doctrine in justification for finding ambiguity. As noted, other scholars have identified the reverse-constitutional avoidance doctrine and have pointed to Bond and other examples. While that insight is invaluable, this article demonstrates that the phenomenon displayed in those cases is actually much broader and more prevalent. The reverse-avoidance doctrine is more properly viewed as but one iteration of absurdity in disguise. Although the scope of the absurdity doctrine has waxed and waned, its hallmark is permitting courts to treat otherwise clear statutory text as ambiguous in order to avoid an absurd result (based on whatever degree or severity of absurdity is accepted in the par-

277 See id. at 2489.

278 Id. at 2488-89 (internal quotation marks omitted) (quoting Fed. Drug Admin. v. Brown \& Williamson Tobacco Corp., 529 U.S. 120, 159 (2000)).

279 See id. at 2492.

280 See id.

281 See id. at 2489-90.

282 See id. at 2490, 2492 (internal quotation marks omitted) (quoting Lamie v. United States Tr., 540 U.S. 526, 536 (2004)).

283 See id. at 2485.

${ }^{284}$ Id. at 2495.

285 See id. at 2496. 
ticular version employed). Not only does the reverse-avoidance doctrine share this hallmark, the cases which exhibit it demonstrate that its application is strikingly similar to analyses in other cases where constitutional consequences do not arise. The key factor is the absence of ex ante ambiguity; the ambiguity finding comes only after examining the consequences of applying apparent statutory meaning ex post.

Finally, unconstitutionality is certainly consistent with some versions of the absurdity doctrine: the presumption that Congress would not intentionally enact an unconstitutional statute rests at least in part on the feeling that it would be ridiculous (or at least unreasonable) for it to do so. Arguably, even the most grossly unfair or anomalous result of applying a statute in a particular case is less a concern than a potentially unconstitutional result. And even Justice Scalia has raised the specter of unconstitutionality as a consideration warranting the use of the absurdity doctrine. ${ }^{286}$ "Reverse avoidance" may share a name and similar concerns with traditional avoidance, but its operation and effect are far more akin to the absurdity doctrine.

\section{E. Yates v. United States}

After harvesting undersized red grouper while fishing in federal waters off the Gulf of Mexico, the defendant, John Yates, instructed a crew member to throw the fish of questionable size overboard in order to prevent their discovery during a routine inspection by the Florida Fish and Wildlife Conservation Commission. ${ }^{287}$ For reasons unknown even to the Court, Yates was charged with federal crimes more than thirty-two months later. ${ }^{288}$ After being indicted and convicted, Yates appealed his conviction of violating 18 U.S.C. $\S 1519$, which provides:

"Whoever knowingly alters, destroys, mutilates, conceals, covers up, falsifies, or makes a false entry in any record, document, or tangible object with the intent to impede, obstruct, or influence the investigation or proper administration of any matter within the jurisdiction of any department or agency of the United States or any case filed under title 11, or in relation to or contemplation of any such matter or case, shall be fined under this title, imprisoned not more than 20 years, or both." 289

Notably, the statute was codified after being enacted as part of the SarbanesOxley Act, sweeping new financial legislation in response to the ethical breaches leading to the implosion of Enron. ${ }^{290}$

Although the majority opinion concluded that a fish is, indeed, a tangible object, the Court nonetheless declined to interpret $\S 1519$ to encompass Yates'

286 See Green v. Bock Laundry Mach. Co., 490 U.S. 504, 528-29 (1989) (Scalia, J., concurring).

287 See Yates v. United States, 135 S. Ct. 1074, 1078 (2015).

288 Id. at 1080.

${ }^{289} I d$. at 1078 (quoting 18 U.S.C. $§ 1519$ ).

$290 \mathrm{Id}$. at 1079. 
conduct. The Court emphasized that the Sarbanes-Oxley Act was designed to address "corporate and accounting deception and cover-ups ..."291 In light of the statutory history, the broad and unqualified term "[t]angible object" in $\S 1519$ should be read to include only tangible objects "use[d] to record or preserve information ...." 292

The Court's opinion is rife with references to the statute's purpose and Congress' likely intent. The Court acknowledged that " $[t]$ he ordinary meaning of an 'object' that is 'tangible,' as stated in dictionary definitions, is 'a discrete ... thing." "'293 However, the majority found that this alone did not preclude a finding of ambiguity, because ambiguity must be determined in context. ${ }^{294}$ To that end, the majority employed a variety of canons of construction, considered statutory headings and titles, and considered the broader purposes of the statute in the context of its passage as part of the Sarbanes-Oxley Act. ${ }^{295}$ Significantly, these tools were used not only to resolve the ambiguity in question, but to bolster the ambiguity finding itself. Like Bond, the Court's approach here was to narrow a broad statutory term to more closely align with its apparent purpose, but under the guise of an ambiguity finding.

\section{CONCLUSION}

Textualism's monumental influence, especially in Supreme Court precedent on interpretation, has elevated statutory text-not legislative purposes or intentions - to the forefront of the interpretive inquiry. Numerous decisions of the Court have instructed that where statutory text is unambiguous, it is to be applied as it is written - even if the outcome is odd or seems ill-advised from a policy perspective. Particularly in an increasingly polarized political environment, the devotion to text offers judges a way to minimize the perception of improper judicial legislating in conflict with our constitutional structure.

Nevertheless, in practice, it is difficult to ignore the implications in a case such as King or Sebelius, where the viability of an entire legislative overhaul of the health insurance market in the United States is at risk. Or in a case where significant international issues and longstanding traditions in our federalist system are at stake, as in Bond. And some cases, such as Bond and Yates, reveal the fairly outlandish, ridiculous results that can occur where very broad statutes are applied in specific circumstances. Debates abound over the desirability and propriety of considering results as part of statutory interpretation. But regardless of one's stance in this debate, the role of consequences in statutory interpretation may be inevitable.

\footnotetext{
${ }^{291} I d$.

292 Id. at 1081.

293 Id. (alteration in original).

294 See id. at 1081-82.

295 See id. at 1081-89.
} 
[Vol. 19:3

The intersection of this inevitability with textualism's success is the root of the development of the phenomenon of "absurdity in disguise." Related to, yet distinct from purposivism, absurdity in disguise allows judges to claim a variety of textualist precepts as their own while embracing results-oriented interpretations that would typically be impermissible under "pure" or strict textualism. Yet this "best of both worlds" approach may suffer from conceptual incoherence if its closeness to purposivism continues to be minimized in the courts. 